Tersedia Online di http://journal2.um.ac.id/index.php/jmsp/

ISSN Online : 2541-4429

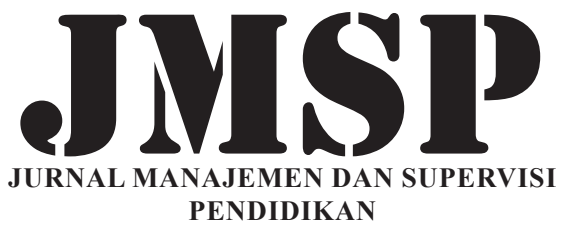

PENDIDIKAN

\title{
PENGARUH GAYA KEPEMIMPINAN, KEMAMPUAN MANAJERIAL, EFIKASI DIRI, DAN PRESTASI BELAJAR TERHADAP KESIAPAN KERJA MAHASISWA
}

\author{
Imam Gunawan', Djum Djum Noor Benty², Desi Eri Kusumaningrum ${ }^{3}$, \\ Raden Bambang Sumarsono ${ }^{4}$, Dika Novita Sari ${ }^{5}$, Firda Dwi Pratiwi, \\ Sari Oktavia Ningsih ${ }^{7}$, Abida Ferindistika Putri ${ }^{8}$, Lim Kim Hui ${ }^{9}$ \\ 1,2,3,4,5,6,7,8 Universitas Negeri Malang, Jalan Semarang 5 Malang Jawa Timur Indonesia \\ ${ }^{9}$ Hankuk University of Foreign Studies, Seoul, South Korea \\ imam.gunawan.fip@um.ac.id
}

\begin{abstract}
The purpose of this study was to determine the effect of leadership style, managerial ability, self-efficacy, and learning achievement on work readiness of students of the Faculty of Education, State University of Malang. This study uses a quantitative approach. The design or design of this study is an ex-post-facto cross-sectional survey and is included in the descriptive-causality research type. The population of this research is all of the management of Ormawa Faculty of Education, State University of Malang. Based on the calculation of Krejcie and Morgan Table (1970), the total population was 269 students, taken as a sample of 158 students. The instrument used in this study was a questionnaire. Analysis of the data that will be used in this study are: (1) descriptive analysis; (2) regression analysis; and (3) path analysis. Based on the results of data analysis, this study concludes: (1) there is a significant influence of leadership style (X1) on students' work readiness (Y); (2) there is a significant influence of managerial ability (X2) on student work readiness of Ormawa (Y); (3) there is a significant effect of self-efficacy (X3) on student work readiness of Ormawa (Y); (4) there is a significant effect of learning achievement (X4) on student work readiness of Ormawa (Y); and (5) there is a significant influence of leadership style (X1), managerial ability (X2), selfefficacy (X3), and learning achievement (X4) on students' work readiness (Y).
\end{abstract}

Keywords: leadership style, managerial ability, self-efficacy, learning achievement, student work readiness

\begin{abstract}
Abstrak: Tujuan penelitian ini adalah untuk mengetahui pengaruh gaya kepemimpinan, kemampuan manajerial, efikasi diri, dan prestasi belajar terhadap kesiapan kerja mahasiswa ormawa Fakultas Ilmu Pendidikan Universitas Negeri Malang. Penelitian ini menggunakan pendekatan kuantitatif. Rancangan atau desain penelitian ini adalah survey cross-sectional ex-post-facto dan termasuk dalam jenis penelitian deskriptif-kausalitas. Populasi penelitian ini adalah seluruh pengurus Ormawa Fakultas Ilmu Pendidikan Universitas Negeri Malang. Berdasarkan perhitungan Tabel Krejcie dan Morgan (1970), jumlah populasi sebanyak 269 orang mahasiswa, diambil sampel penelitian sebanyak 158 orang mahasiswa. Instrumen yang digunakan dalam penelitian ini adalah angket. Analisis data yang akan digunakan dalam penelitian ini adalah: (1) analisis deskriptif; (2) analisis regresi; dan (3) analisis jalur. Berdasarkan hasil analisis data, penelitian ini menyimpulkan: (1) ada pengaruh yang signifikan gaya kepemimpinan (X1) terhadap kesiapan kerja mahasiswa ormawa (Y); (2) ada pengaruh yang signifikan kemampuan manajerial (X2) terhadap kesiapan kerja mahasiswa ormawa (Y); (3) ada pengaruh yang signifikan efikasi diri (X3) terhadap kesiapan kerja mahasiswa ormawa (Y); (4) ada pengaruh yang signifikan prestasi belajar (X4) terhadap kesiapan kerja mahasiswa ormawa (Y); dan (5) ada pengaruh yang signifikan gaya kepemimpinan (X1), kemampuan manajerial (X2), efikasi diri (X3), dan prestasi belajar (X4) terhadap kesiapan kerja mahasiswa ormawa $(\mathrm{Y})$.
\end{abstract}

Kata Kunci: gaya kepemimpinan, kemampuan manajerial, efikasi diri, prestasi belajar, kesiapan kerja mahasiswa

Kesiapan kerja mahasiswa merupakan faktor yang penting terutama setelah mahasiswa menyelesaikan studinya di perguruan tinggi. Tingkat kesiapan mahasiswa memasuki dunia kerja dipengaruhi oleh banyak faktor. Sudah menjadi tanggung jawab pergerzuan tinggi untuk menyiapkan para mahasiswanya 
untuk dapat memiliki bekal yang cukup untuk memasuki dunia kerja. Hal yang perlu diperhatikan adalah bahwa tantangan dan perubahan tuntutan dunia usaha dan dunia industri selalu berubah. Tentunya hal tersebut juga mempengaruhi lanskap bidang-bidang pekerjaan yang juga terus berkembang. Era Industri 4.0 yang saat ini sedang bergulir pun juga menuntut seseorang (dan juga mahasiswa) untuk memiliki keterampilan-keterampilan tertentu agar ia sukses di era yang serba tidak menentu.

Ada sepuluh keterampilan yang setidaknya harus dikuasai oleh seorang mahasiswa agar ia dapat berhasil di era sekarang ini, yaitu: complex problem solving; critical thinking; creativity; people management; coordinating with others; emotional intelligence; judgment and decision making; service orientation; negotiation; dan cognitive flexibility. Jika mengacu pada tuntutan yang ada, maka menyiapkan mahasiswa untuk dapat memasuki dunia kerja tidak cukup hanya dalam kegiatan perkuliahan saja. Menyiapkan mahasiswa agar siap memasuki dunia kerja membutuhkan program yang tidak hanya mengasah kemampuan akademik saja, namun juga menyangkut aspek-aspek atau keterampilan-keterampilan lain yang selaras dengan tuntutan perubahan. Keterampilan-keterampilan tersebut harus diasah dengan baik sebelum mahasiswa lulus.

Kesiapan kerja mahasiswa merupakan kondisi yang harus dipersiapkan oleh mahasiswa dan juga perguruan tinggi sebelum mahasiswa yang bersangkutan menyelesaikan studinya. Sehingga ketika mahasiswa lulus ia akan bekerja dan/atau dapat menciptakan lapangan kerja sendiri dengan masa tunggu yang relatif tidak lama. Baiti, dkk., (2017) menyatakan bahwa kesiapan kerja mahasiswa menyangkut faktor mahasiswa yang bersangkutan harus dapat mengimbangi tuntutan produktivitas dan kualitas serta kinerja suatu organisasi. Perguruan tinggi dalam hal ini tentu memiliki kewajiban untuk menjalin kerjasama dengan dunia usaha dan dunia industri, agar kompetensi lulusan perguruan tinggi sesuai dengan kebutuhan dunia kerja. Inilah yang disebut dengan link and match, yaitu suatu upaya sinkronisasi kurikulum perguruan tinggi dengan dunia kerja.

Seperti yang telah diuraikan, tidak cukup hanya bidang akademik saja untuk menyiapkan mahasiswa agar ia memiliki kesiapan yang baik dalam memasuki dunia kerja. Perguruan tinggi agar mewadahi bakat-bakat mahasiswa yang heterogen, agar bakat-bakat tersebut dapat digunakan sebagai mahasiswa siap memasuki dunia kerja. Keberadaan Organisasi Kemahasiswaan (ormawa) dalam hal ini memiliki peran yang sangat krusial. Berbagai minat mahasiswa dapat ditampung dalam kegiatan ormawa yang juga memiliki banyak bidang peminatan. Berbagai kemampuan mahasiswa akan diasah dalam kegiatan ormawa. Sehingga tidak hanya kemampuan akademik saja yang dapat dimiliki oleh mahasiswa. Mahasiswa dapat mengasah kemampuannya dalam kegiatan ormawa yang diharapkan dapat meningkatkan kesiapan kerja mahasiswa.

Hal krusial yang dapat dipetik dari keaktifan mahasiswa dalam kegiatan ormawa adalah belajar mengorganisasikan kegiatan, belajar memimpin, belajar dipimpin, dan belajar berkomunikasi, seperti menyampaikan pendapat, mempertahankan gagasan, atau bernegosiasi (Gunawan, 2017; Argadinata \& Gunawan, 2019; Gunawan, 2018). Ormawa dapat dijadikan wahana mahasiswa dalam mengembangkan jiwa dan gaya kepemimpinannya. Gaya kepemimpinan merupakan sekumpulan norma dan perilaku yang digunakan oleh seorang pemimpin mempengaruhi perilaku orang lain. Astuti (2011) berdasarkan hasil penelitiannya menyimpulkan bahwa bahwa gaya kepemimpinan mahasiswa berkaitan mahasiswa dalam melakukan komunikasi, memberikan motivasi, mendeskripsikan tujuan organisasi, dan pembuatan keputusan. Mahasiswa sebagai pemimpin masa depan, sudah selayaknya kemampuan memimpin mahasiswa diasah dalam kehidupan kampus.

Gaya kepemimpinan mahasiswa merupakan variabel penting dalam membentuk mahasiswa. Setiap kelompok mahasiswa akan memilih gaya kepemimpinnya sendiri yang sesuai dengan karakteristik dan tujuan kelompok. Sebaliknya, pribadi pemimpin akan menentukan semangat kelompok yang dipimpinnya (Stiawan, 2013; Gunawan, dkk., 2019a; Bafadal, dkk., 2019). Jika mengacu pada literatur, maka akan dapat banyak ragam para ahli mengemukakan tentang berbagai gaya kepemimpinan. Thoha (2014) mengemukakan ada dua gaya kepemimpinan, yaitu gaya otoriter dan demokratis. Gaya otoriter menekankan pada kekuatan dan posisi seorang pemimpin. Gaya demokratis menekankan pada partisipasi semua anggota organisasi. Hal sedana dikemukakan oleh Kartono (2010) yang menyatakan gaya kepemimpinan ada tiga, yaitu: otoriter, demokratis, dan laissez faire. Gaya laissez faire adalah gaya seorang pemimpin manakala ia membiarkan para bawahannya melakukan semaunya sendiri. 
Faktor kepemimpinan dalam suatu organisasi memegang peranan yang penting. Orang yang menggerakkan dan mengarahkan organisasi dalam mencapai tujuan adalah seorang pemimpin, dan itu merupakan tugas yang tidak mudah. Pemimpin harus memahami setiap perilaku bawahan yang berbedabeda. Seorang pemimpin harus mengetahui betul fungsi pemimpin dan sekaligus mengetahui unsur-unsur kepemimpinan sebagai aktivitas mempengaruhi, kemampuan mengajak, mengarahkan, menciptakan dan mencetuskan ide. Robbins dan Judge (2017) menyebutkan bahwa kepemimpinan merupakan kemampuan untuk mempengaruhi suatu kelompok guna mencapai sebuah visi atau serangkaian tujuan yang direncanakan.

Seorang pemimpin dalam organisasi memerlukan beberapa keterampilan dalam menjalankan roda organisasi. Keterampilan manajerial adalah keterampilan atau kualitas yang dicari organisasi dalam diri seorang pemimpin untuk mengelola organisasi. Keterampilan manajerial adalah keterampilan untuk mengatur, mengoordinasikan, dan menggerakkan para bawahan ke arah pencapaian tujuan yang telah ditentukan organisasi. Keterampilan manajerial adalah kemampuan seseorang dalam mengelola sumber daya organisasi berdasarkan kompetensi yang ditetapkan dalam rangka mencapai tujuan yang ditentukan (Kholiq, 2011; Kusumaningrum, dkk., 2017; Gunawan, 2019).

Kepemimpinan mahasiswa akan lebih baik manakala diikuti dengan keterampilan manajerial yang baik dalam diri mahasiswa. Keterampilan manajerial digunakan oleh seorang pemimpin dalam menjalankan organisasi. Katz (2017) mengemukakan keterampilan manajerial yang harus dimiliki oleh seorang pemimpin adalah keterampilan teknis, keterampilan hubungan manusia, dan keterampilan konseptual. Keterampilan teknis adalah keterampilan menjalankan pekerjaan sesuai dengan tugas yang diembannya. Keterampilan teknis ini harus dimiliki pemimpin pada level bawah. Keterampilan konseptual berkaitan dengan kemampuan seseorang dalam memikirkan perencanaan dan strategi organisasi. Keterampilan ini harus dimiliki oleh pemimpin pada level atas. Keterampilan hubungan manusia merupakan keterampilan yang berkaitan dengan cara berkomunikasi dengan orang lain. Keterampilan ini semua orang pemimpin harus memiliki. Keterampilan manajerial mendukung keefektifan seorang pemimpin dalam mempengaruhi para anggotanya untuk bekerja dengan baik.

Selain faktor jiwa kepemimpinan, efikasi diri (self-efficacy) mahasiswa juga sangat penting dalam kehidupan mahasiswa. Efikasi diri mahasiswa merupakan kepercayaan diri yang dimiliki mahasiswa merasa yakin akan sukses, dapat mengerjakan tugas dengan baik, dan optimis terhadap masa depan. Efikasi diri adalah penilaian terhadap diri sendiri, apakah dapat melakukan tindakan yang baik atau buruk, tepat atau salah, bisa atau tidak bisa mengerjakan sesuai dengan yang dipersyaratkan (Alwisol, 2007; Gunawan, dkk., 2019b). Efikasi diri timbul dari perubahan bertahap pada kognitif yang kompleks, sosial, linguistik, dan/atau keahlian fisik melalui pengalaman. Seseorang akan mempertimbangkan, menggabungkan, dan menilai informasi berkaitan dengan kemampuan mereka kemudian memutuskan berbagai pilihan dan usaha yang sesuai (Gist, 1987; Kusumaningrum, dkk., 2018).

Efikasi diri merupakan kepercayaan seseorang terhadap kemampuannya sendiri untuk melaksanakan tugas. Orang yang percaya diri dengan kemampuannya cenderung untuk berhasil, sedangkan orang yang selalu merasa tidak mampu cenderung untuk gagal. Individu yang memiliki efikasi diri tinggi akan mencapai suatu kinerja yang lebih baik karena individu ini memiliki motivasi yang kuat, tujuan yang jelas, emosi yang stabil dan kemampuannya untuk memberikan kinerja atas aktivitas atau perilaku dengan sukses (Bandura, 1991; Bandura, 1978; Bandura, 1997). Berbeda individu dengan efikasi diri rendah yang akan cenderung tidak mau berusaha atau lebih menyukai kerjasama dalam situasi yang sulit dan tingkat kompleksitas tugas yang tinggi (Bandura, 1993; Bandura, 1986; Bandura, 1989; Bandura, 2005). Efikasi diri tidak muncul begitu saja, namun dibentuk oleh banyak unsur, seperti pengaruh keluarga, lingkungan, dan teman sebaya. Mahasiswa yang memiliki efikasi diri tinggi akan selalu optimis.

Mahasiswa akan tinggi efikasi dirinya manakala ia juga memiliki prestasi belajar yang baik. Prestasi belajar merupakan capaian mahasiswa dalam menempuh studi yang dituangkan dalam indeks prestasi. Prestasi mahasiswa menjadi salah satu tolak ukur keberhasilan mahasiswa menempuh studi di perguruan tinggi. Prestasi belajar merupakan kemampuan yang diperoleh individu setelah proses belajar berlangsung, yang dapat memberikan perubahan tingkah laku baik pengetahuan, pemahaman, sikap dan 
keterampilan peserta didik sehingga menjadi lebih baik dari sebelumnya (Sjukur, 2012; Gunawan, dkk., 2018a). Prestasi belajar peserta didik berupa aspek kognitif, psikomotor, dan aspek afektif (Setiawan, 2008; Gunawan, dkk., 2018b). Prestasi belajar mahasiswa dalam penelitian ini adalah capaian mahasiswa yang tercermin dalam indeks prestasi mahasiswa (IPK).

Prestasi belajar menggambarkan hasil penguasaan mahasiswa terhadap materi-materi yang telah dipelajari yang dapat dilihat dari aspek kognitif, psikomotorik, dan afektif. Sedangkan menurut Mulyasa (2004) prestasi belajar merupakan hasil interaksi berbagai faktor. Faktor-faktor yang mempengaruhi proses dan prestasi belajar peserta didik dapat digolongkan menjadi empat yaitu: (1) bahan atau materi yang dipelajari; (2) lingkungan; (3) faktor instrumental; dan (4) kondisi siswa. Faktor-faktor tersebut memberikan kontribusi tertentu terhadap prestasi belajar. Prestasi belajar adalah penguasaan pengetahuan atau keterampilan yang dikembangkan oleh matapelajaran, lazimnya ditunjukkan dengan nilai yang diberikan guru (Tu'u, 2004). Prestasi belajar dapat tercermin dalam dimensi proses kognitif siswa (Anderson \& Krathwohl, 2001).

Kesiapan kerja mahasiswa dipengaruhi oleh banyak variabel. Kesiapan kerja akan lebih optimal dengan dukungan dari berbagai variabel. Variabel gaya kepemimpinan, kemampuan manajerial, efikasi diri, dan prestasi belajar mahasiswa merupakan variabel yang secara teoritik dapatmempengaruhi kesiapan kerja mahasiswa. Gaya kepemimpinan mahasiswa menjadi modal awal mahasiswa dalam menyongsong masa depan. Mahasiswa dengan jiwa kepemimpinan dapat memiliki kapasitas bekerjasama dengan orang lain. Kemampuan manajerial merupakan bekal mahasiswa dalam bekerja dengan orang lain. Efikasi diri memperkuat mahasiswa dalam berusaha mencapai tujuan dan menyelesaikan tugas yang diembannya. Dan dengan prestasi belajar mahasiswa yang baik, dunia usaha akan lebih menambah kepercayaannya untuk menerima lulusan sebagai tenaga kerja. Tujuan penelitian ini adalah untuk mengetahui pengaruh gaya kepemimpinan, kemampuan manajerial, efikasi diri, dan prestasi belajar terhadap kesiapan kerja mahasiswa ormawa Fakultas Ilmu Pendidikan Universitas Negeri Malang.

\section{METODE}

Berdasarkan tujuan penelitian, penelitian ini menggunakan pendekatan kuantitatif. Rancangan atau desain penelitian ini adalah survey cross-sectional ex-post-facto dan termasuk dalam jenis penelitian deskriptif-kausalitas. Penelitian survey adalah penelitian yang mengambil sampel dari suatu populasi dengan menggunakan angket sebagai alat pengumpulan data utama yang bertujuan untuk memberikan penjelasan mengenai hubungan kausal antara variabel-variabel melalui pengujian hipotesis (Singarimbun \& Effendi, 1989). Penelitian ini mengkaji tentang: pengaruh gaya kepemimpinan (X1), kemampuan manajerial (X2), efikasi diri (X3), dan prestasi belajar mahasiswa (X4) sebagai variabel bebas atau prediktor, dan kesiapan kerja mahasiswa (Y) sebagai variabel terikat atau kriterium.

Populasi penelitian ini adalah seluruh mahasiswa pengurus ormawa Fakultas Ilmu Pendidikan (FIP) Universitas Negeri Malang (UM) Periode 2019, sebanyak 269 orang mahasiswa, diambil sampel penelitian sebanyak 158 orang mahasiswa. Jumlah sampel ini diperoleh berdasarkan perhitungan rumus Tabel Krejcie \& Morgan (1970). Teknik proporsional random sampling untuk menentukan besarnya sampel di setiap ormawa. Proporsional random sampling digunakan karena karakteristik populasi terdiri dari kategori, kelompok, atau golongan yang setara atau sejajar yang diduga kuat berpengaruh pada hasil penelitian (Winarsunu, 2012; Gunawan, 2016). Penentuan jumlah sampel tiap ormawa menggunakan rumus (Riduwan \& Kuncoro, 2017) yaitu.

$$
\begin{array}{ll}
\mathrm{n}_{\mathrm{i}}=\frac{\mathrm{N}_{\mathrm{i}}}{\mathrm{N}} \times \mathrm{S} \quad & \quad \text { Keterangan: } \\
\mathrm{ni}= & \text { Jumlah sampel setiap ormawa. } \\
\mathrm{Ni}= & \text { Jumlah populasi setiap ormawa. } \\
\mathrm{N}= & \text { Jumlah populasi keseluruhan. } \\
\mathrm{S}= & \text { Jumlah sampel yang diambil sesuai dengan rumus Tabel Krejcie dan Morgan. }
\end{array}
$$


Adapun hasil perhitungan besar sampel secara proporsional dan hasilnya untuk tiap ormawa, dapat dilihat dalam Tabel 1.

Tabel 1 Jumlah Populasi dan Sampel Penelitian Ormawa FIP UM

\begin{tabular}{|c|l|c|c|}
\hline No & \multicolumn{1}{|c|}{ Ormawa } & Jumlah Populasi & Jumlah Sampel \\
\hline 1 & DMF & 21 orang & 12 orang \\
\hline 2 & BEMFA & 36 orang & 21 orang \\
\hline 3 & HMJ BK & 29 orang & 17 orang \\
\hline 4 & HMJ TEP & 35 orang & 21 orang \\
\hline 5 & HMJ AP & 31 orang & 18 orang \\
\hline 6 & HMJ PLS & 31 orang & 18 orang \\
\hline 7 & HMJ KSDP & 32 orang & 19 orang \\
\hline 8 & HMJ PLB & 30 orang & 12 orang \\
\hline 9 & KKM 3 Blitar & 34 orang & 20 orang \\
\hline \multicolumn{2}{|c|}{ Jumlah total } & 269 orang & 158 orang \\
\hline
\end{tabular}

Instrumen yang digunakan dalam penelitian ini adalah angket. Susunan angket berbentuk skala empat dengan kecenderungan rentang ke sebelah kanan mengarah kepada keputusan penilaian rendah atau berkode satu, dan sebaliknya rentang ke sebelah kiri mengarah kepada keputusan penilaian tinggi berkode empat. Instrumen yang baik harus dapat memenuhi dua persyaratan penting yaitu valid dan reliabel (Soetopo, 2001; Setyadin, 2005b; Ary, dkk., 1982). Untuk dapat mengetahui instrumen penelitian tersebut dapat dikatakan benar-benar valid dan reliabel, maka perlu dilakukan uji coba instrumen terhadap beberapa responden. Tingkat validitas butir soal angket digunakan teknik korelasi product moment dari Pearson.

Pengujian validitas butir soal angket tersebut mengunakan bantuan komputer dengan program analisis statistik IBM SPSS Statistics 20. Uji coba terhadap instrumen dalam penelitian ini dilaksanakan di UKM KSR PMI Unit Universitas Negeri Malang. Responden uji coba penelitian berjumlah 35 orang anggota UKM KSR PMI Unit Universitas Negeri Malang. Kriteria butir soal angket dapat dinyatakan valid apabila harga rhitung $>$ rtabel dan nilai signifikansi butir soal yang valid $<0,05$ (Santoso, 2010). Sedangkan harga rtabel untuk $\mathrm{N}=35$ adalah 0,334 .

Hasil uji validitas variabel gaya kepemimpinan mahasiswa (X1) dari 10 item, semua item dinyatakan valid. Hasil uji validitas variabel kemampuan manajerial mahasiswa (X2) dari 18 item, yang dinyatakan valid sebanyak 17 item dan tidak valid sebanyak 1 item. Hasil uji validitas variabel efikasi diri mahasiswa (X3) dari 14 item, yang dinyatakan valid sebanyak 13 item dan tidak valid sebanyak 1 item. Variabel prestasi belajar mahasiswa (X4) tidak dilakukan uji validitas, sebab data diambil dari nilai IPK mahasiswa yang merupakan jenis data nonmetrik. Hasil uji validitas variabel kesiapan kerja mahasiswa (Y) dari 21 item, yang dinyatakan valid sebanyak 18 item dan tidak valid sebanyak 3 item. Selanjutnya item soal yang digunakan dalam pengumpulan data penelitian kepada responden adalah item yang valid. Sedangkan item yang tidak valid tidak digunakan atau item digugurkan.

Untuk menguji tingkat reliabilitas angket digunakan rumus Alpha Cronbach melalui IBM SPSS Statistics 20. Kriteria angket dapat dinyatakan reliabel apabila harga ralpha $>$ rtabel (Santoso, 2010). Sedangkan harga rtabel untuk $\mathrm{N}=35$ adalah 0,334 . Hasil perhitungan ralpha untuk variabel gaya kepemimpinan mahasiswa $(X 1)=0,799$; variabel kemampuan manajerial mahasiswa $(X 2)=0,864$; dan variabel efikasi diri mahasiswa $(X 3)=0,756$; dan variabel kesiapan kerja mahasiswa $(Y)=0,859$. Seluruh ralpha dari keempat variabel tersebut $>0,334$. Sehingga dapat disimpulkan bahwa item dalam angket keempat variabel tersebut sudah reliabel.

Analisis data yang akan digunakan dalam penelitian ini adalah: (1) analisis deskriptif; (2) analisis regresi; dan (3) analisis jalur. Adapun langkah yang digunakan dalam mendeskripsikan hasil penelitian ini adalah dengan menentukan kualifikasi, menentukan persentase, dan kategori item pernyataan. Menentukan kualifikasi bertujuan untuk mengetahui bagaimana interval nilai masing-masing variabel 
berada dalam kategori: sangat tinggi, tinggi, sedang, rendah, dan sangat rendah. Rumus yang digunakan sebagai acuan dalam menentukan kualifikasi setiap variabel dengan menggunakan rumus formula stanfive, seperti pada Tabel 2.

Tabel 2 Rumus Formula Stanfive

\begin{tabular}{|c|l|c|}
\hline No & \multicolumn{1}{|c|}{ Formula Rumus } & Kategori \\
\hline 1 & $(\overline{\mathrm{X}}+\mathbf{1 , 5} \mathrm{DS})<\mathrm{X}$ & Sangat tinggi \\
\hline 2 & $(\overline{\mathrm{X}}+\mathbf{0 , 5} \mathrm{DS})<\mathrm{X}<(\overline{\mathrm{X}}+\mathbf{1 , 5} \mathrm{DS})$ & Tinggi \\
\hline 3 & $(\overline{\mathrm{X}}-\mathbf{0 , 5} \mathrm{DS})<\mathrm{X}<(\overline{\mathrm{X}}+\mathbf{0 , 5} \mathrm{DS})$ & Sedang \\
\hline 4 & $(\overline{\mathrm{X}}-\mathbf{1 , 5} \mathrm{DS})<\mathrm{X}<(\overline{\mathrm{X}}-\mathbf{0 , 5} \mathrm{DS})$ & Rendah \\
\hline 5 & $\mathrm{X}<(\overline{\mathrm{X}}-\mathbf{1 , 5} \mathrm{DS})$ & Sangat rendah \\
\hline
\end{tabular}

Sumber: Wiyono dan Sunarni (2009)

Uji asumsi data dilakukan untuk mengetahui apakah data yang diperoleh telah memenuhi syarat untuk dianalisis dengan analisis regresi dan analisis jalur (path analysis). Data penelitian ini tergolong data metrik yaitu data primer yang diperoleh dari pengukuran langsung oleh peneliti sendiri, sehingga uji persyaratan analisis mencakup normalitas, homogenitas, linieritas, dan multikolinieritas sebelum analisis jalur dilakukan. Uji normalitas, homogenitas, linieritas, dan multikolinieritas akan menggunakan bantuan program analisis statistik IBM SPSS Statistics 20. Variabel yang dianalisis harus dari data populasi penelitian berdistribusi normal (Sudarmanto, 2005); data homogen yang akan dianalisis dengan regresi varians yang relatif kecil (Setyadin, 2007); hubungan variabel bebas dengan variabel terikat harus linier (Alhusin, 2003); dan kasus multikolinieritas sebagai standar estimasi (Mason., dkk., 1988).

Uji normalitas digunakan untuk kepentingan penarikan kesimpulan. Normalitas akan tercapai apabila skor pada setiap variabel dalam model mengikuti distribusi normal (Winarsunu, 2012). Uji normalitas sebaran bahwa distribusi data variabel bebas dan terikat adalah normal. Uji normalitas dilakukan dengan uji nilai Kolmogorov Smirnov menggunakan program analisis statistik IBM SPSS Statistics 20. Apabila nilai probabilitas $\geq 0,05$ maka data dinyatakan berdistribusi normal, sebaliknya jika nilai probabilitas < 0,05 maka data dinyatakan berdistribusi tidak normal (Hadi, dkk., 2018).

Uji homogenitas digunakan untuk mengetahui bahwa data yang akan dianalisis dengan regresi variansnya relatif kecil (Setyadin, 2007; Hadi, dkk., 2018). Data homogen apabila skor-skor variabel endogen untuk setiap skor tertentu pada variabel eksogen selalu sama atau hampir sama. Variabel yang masuk ke dalam persamaan regresi ganda datanya harus homogen. Homogenitas dapat diasumsikan apabila indeks skor-skor variabel endogen untuk setiap skor tertentu variabel eksogen selalu sama atau hampir sama. Artinya varian kesalahan pada suatu nilai X adalah konstan. Asumsi homogenitas dilihat dengan pemeriksaan indeks residu baku (standardized residual zress) dalam distribusi.

Subyek yang memiliki skor ekstrem tinggi atau rendah atau disebut outlier dapat menyebabkan bilangan-bilangan statistik hasil analisa kurang mencerminkan keadaan mayoritas subyek. Uji homogenitas digunakan untuk mengetahui bahwa data yang akan dianalisis dengan regresi variansnya relatif kecil (Setyadin, 2007). Uji homogenitas dilakukan dengan uji nilai Homogeneity of Variance Test menggunakan program analisis statistik IBM SPSS Statistics 20. Apabila nilai probabilitas $\leq 0,05$ maka data dinyatakan homogen, sebaliknya jika nilai probabilitas $>0,05$ maka data dinyatakan tidak homogen (Gunawan, 2016; Hadi, dkk., 2018; Gunawan, 2013).

Uji linieritas digunakan untuk mengetahui linier tidaknya hubungan antar masing-masing variabel penelitian (Cohen, 2013). Uji linieritas menggunakan scatter diagram dan garis best fit (Sudjana, 1998). Variabel bebas dan variabel terikat berhubungan secara linear artinya apabila dibuat scatter diagram dari nilai-nilai variabel bebas dan variabel terikat dapat ditarik garis lurus pada pancaran titik-titik kedua nilai variabel tersebut (Salladien, 1997). Mendapatkan scatter diagram dan garis best fit menggunakan bantuan program IBM SPSS Statistics 20, dengan ketentuan jika antara variabel bebas dan variabel terikat membentuk atau mendekati garis lurus, maka data tersebut bersifat linier. Sebaliknya jika data antara 
variabel bebas dan variabel terikat tidak membentuk atau mendekati garis lurus, maka data tersebut tidak bersifat linier. Uji linieritas dilakukan dengan uji nilai Curve Estimation Test menggunakan program analisis statistik IBM SPSS Statistics 20 . Apabila nilai probabilitas $\leq 0,05$ maka data dinyatakan linier, sebaliknya jika nilai probabilitas $>0,05$ maka data dinyatakan tidak linier (Gunawan, 2016).

Uji multikolinieritas digunakan untuk mengetahui kesalahan standar estimasi model dalam penelitian. Karim \& Hadi (2007) mengemukakan akibat yang muncul jika sebuah model regresi berganda memiliki kasus multikolinieritas adalah kesalahan standar estimasi akan cenderung meningkatkan dengan bertambahnya variabel eksogen yang masuk pada model. Sehingga signifikansi yang digunakan akan menolak hipotesis nol akan semakin besar. Akibatnya model regresi yang diperoleh tidak sahih (valid) untuk menaksir variabel endogen.

Hal ini sesuai dengan pendapat Mason, dkk., (1988) yang mengemukakan the independent variables should not be highly correlated, when the independent variables are correlated, this is a multicolinearity. Variabel independen sama sekali tidak sangat berhubungan, bila variabel independen berhubungan, ini adalah kasus multikolinieritas. Cara menguji adanya kasus multikolinieritas dalam penelitian ini adalah dengan melihat nilai variance inflating factor (VIF). Apabila nilai VIF suatu model kurang dari 10, maka model tersebut dinyatakan bebas kasus multikolinieritas (Karim \& Hadi, 2007). Mendapatkan nilai VIF menggunakan bantuan program IBM SPSS Statistics 20.

Analisis jalur digunakan untuk menemukan penjelasan mengenai pola-pola hubungan langsung dan tidak langsung dari suatu model kausal yang disusun berdasarkan pertimbangan teoritis dan pengetahuan peneliti (Winarsunu, 2012). Analisis jalur menggunakan persamaan regresi karena koefisien betanya yang digunakan untuk menghitung koefisien path. Alasan penelitian ini menggunakan analisis jalur (path analysis) adalah secara teoritik hubungan variabel X1 dengan Y bersifat recursive dan hubungan variabel eksogen dengan variabel endogen cenderung linear. Hubungan recursive dimaksud adalah variabel X1 berhubungan dengan Y melalui X yang lain (Setyadin, 2007; Hadi, dkk., 2018). Analisis jalur digunakan untuk mengetahui hubungan variabel eksogen dengan variabel endogen melalui perantara variabel eksogen yang lain. Untuk mengetahui hubungan variabel eksogen dengan variabel endogen melalui perantara variabel eksogen yang lain digunakan persamaan matematika pemilihan struktur sebagai berikut:

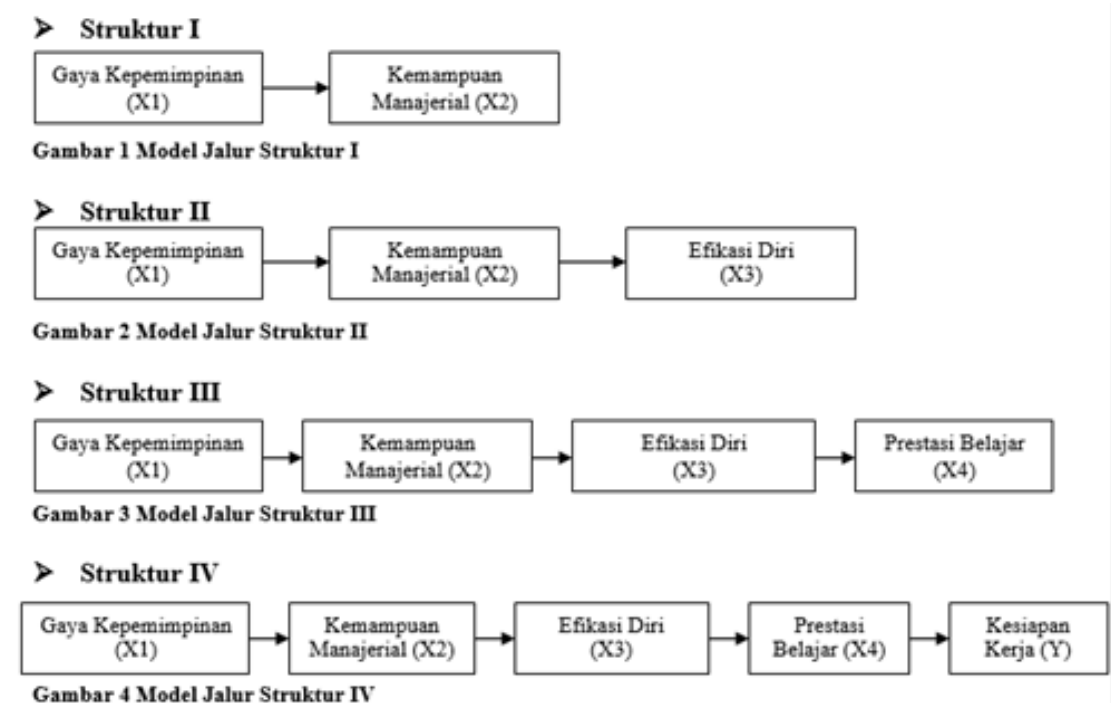

Adapun persamaan matematikanya mengacu pada rumusan yang dikemukakan oleh Riduwan dan Kuncoro (2017) yaitu:

$\square$ Struktur I

$\mathrm{Y}=\mathrm{yx} 1 \mathrm{X} 1+\rho \mathrm{y} \varepsilon$

Struktur II

$\mathrm{Y}=\rho \mathrm{yx} 1 \mathrm{X} 1+\rho \mathrm{yx} 2 \mathrm{X} 2+\rho \mathrm{y} \varepsilon 1$ 


\section{Struktur III}

$\mathrm{Y}=\rho \mathrm{yx} 1 \mathrm{X} 1+\rho \mathrm{yx} 2 \mathrm{X} 2+\rho \mathrm{yx} 3 \mathrm{X} 3+\rho \mathrm{y} \varepsilon 1$

Struktur IV

$\mathrm{Y}=\rho \mathrm{yx} 1 \mathrm{X} 1+\rho \mathrm{yx} 2 \mathrm{X} 2+\rho \mathrm{yx} 3 \mathrm{X} 3+\rho \mathrm{yx} 4 \mathrm{X} 4+\rho \mathrm{y} \varepsilon 1$

Perhitungan analisis jalur dalam penelitian ini diselesaikan melalui analisis regresi dengan menemukan koefisien korelasi dan koefisien beta. Analisis regresi struktur pertama digunakan untuk menemukan koefisien beta dari hubungan variabel gaya kepemimpinan (X1) dengan kemampuan manajerial (X2), rumus yang digunakan sebagai berikut:

$\mathrm{X} 2=\beta 0+\beta 1 \mathrm{X} 1+\varepsilon$

Keterangan:

$\mathrm{X} 2=\quad$ Kriterium (endogen).

$\beta 0=\quad$ Bilangan kostanta (beta 0 ).

$\beta 1=\quad$ Bilangan konstanta (beta X1).

$\mathrm{X} 1=\quad$ Bilangan prediktor (eksogen).

$\varepsilon=\quad$ Error (Draper \& Smith, 2016).

Analisis regresi struktur kedua digunakan untuk menemukan koefisien beta dari hubungan variabel gaya kepemimpinan (X1) dan kemampuan manajerial (X2) dengan efikasi diri (X3), rumus yang digunakan sebagai berikut:

$\mathrm{X} 3=\beta 0+\beta 1 \mathrm{X} 1+\beta 2 \mathrm{X} 2+\varepsilon$

Keterangan:

$\mathrm{X} 3=\quad$ Kriterium (endogen).

$\beta 0=\quad$ Bilangan kostanta (beta 0$)$.

$\beta 1=\quad$ Bilangan konstanta (beta X1).

$\mathrm{X} 1=\quad$ Bilangan prediktor (eksogen),

$\beta 2=\quad$ Bilangan konstanta X2 (beta X2).

$\mathrm{X} 2=\quad$ Bilangan prediktor (eksogen).

$\varepsilon=\quad$ Error (Draper \& Smith, 2016).

Analisis regresi struktur ketiga digunakan untuk menemukan koefisien beta dari hubungan variabel gaya kepemimpinan (X1), kemampuan manajerial (X2), dan efikasi diri (X3) dengan prestasi belajar mahasiswa (X4), rumus yang digunakan sebagai berikut:

$\mathrm{X} 4=\beta 0+\beta 1 \mathrm{X} 1+\beta 2 \mathrm{X} 2+\beta 3 \mathrm{X} 3+\varepsilon$

Keterangan:

$\mathrm{X} 4=\quad$ Kriterium (endogen).

$\beta 0=\quad$ Bilangan kostanta (beta 0$)$.

$\beta 1=\quad$ Bilangan konstanta (beta X1).

$\mathrm{X} 1=\quad$ Bilangan prediktor (eksogen) .

$\beta 2=\quad$ Bilangan konstanta X2 (beta X2).

$\mathrm{X} 2=\quad$ Bilangan prediktor (eksogen).

$\beta 3=\quad$ Bilangan konstanta X3 (beta X3).

$\mathrm{X} 3=\quad$ Bilangan prediktor (eksogen).

$\varepsilon=\quad$ Error (Draper \& Smith, 2016).

Analisis regresi struktur keempat digunakan untuk menemukan koefisien beta dari hubungan variabel gaya kepemimpinan (X1), kemampuan manajerial (X2), efikasi diri (X3), dan prestasi belajar mahasiswa (X4) dengan kesiapan kerja mahasiswa (Y), rumus yang digunakan sebagai berikut: 


$$
\begin{aligned}
& \hat{\mathrm{Y}}=\beta 0+\beta 1 \mathrm{X} 1+\beta 2 \mathrm{X} 2+\beta 3 \mathrm{X} 3++\beta 4 \mathrm{X} 4+\varepsilon \\
& \text { Keterangan: } \\
& \hat{Y}=\quad \text { Kriterium (endogen). } \\
& \beta 0=\quad \text { Bilangan kostanta (beta } 0) \text {. } \\
& \beta 1=\quad \text { Bilangan konstanta (beta X1). } \\
& \mathrm{X} 1=\quad \text { Bilangan prediktor (eksogen). } \\
& \beta 2=\quad \text { Bilangan konstanta X2 (beta X2). } \\
& \mathrm{X} 2=\quad \text { Bilangan prediktor (eksogen). } \\
& \beta 3=\quad \text { Bilangan konstanta X3 (beta X3). } \\
& \mathrm{X} 3=\quad \text { Bilangan prediktor (eksogen). } \\
& \beta 4=\quad \text { Bilangan konstanta X4 (beta X4). } \\
& \mathrm{X} 4=\quad \text { Bilangan prediktor (eksogen). } \\
& \varepsilon=\quad \text { Error (Draper \& Smith, 2016). }
\end{aligned}
$$

\section{HASIL}

\section{Deskripsi Data}

Deskripsi data bertujuan untuk mengetahui tingkatan setiap variabel. Data penelitian setiap variabel dihitung: mean, deviasi standar, skor maksimum, dan skor minimum. Selanjutnya data setiap variabel disajikan dalam bentuk tabel distribusi frekuensi. Distribusi frekuensi dengan mengacu pada formula rumus stanfive (Tabel 2). Selain itu disajikan deskripsi kategori setiap item, bertujuan untuk mengetahui item yang termasuk kategori tinggi dan rendah, dengan dibanding mean seluruh item dalam setiap variabel.

Variabel gaya kepemimpinan (X1) dengan indikator: autokratis; birokratik; diplomatis; partisipatif; dan free rein leader, diukur dengan 10 item. Hasil analisis data terhadap variabel tersebut menunjukkan nilai: mean $=33,56$; deviasi standar $=4,10$; skor maksimum $=40$; dan skor minimum $=23$. Berdasarkan hasil perhitungan dengan formula stanfive (Tabel 2) diperoleh distribusi frekuensi seperti pada Tabel 3.

Tabel 3 Distribusi Frekuensi Variabel Gaya Kepemimpinan (X1)

\begin{tabular}{|l|c|c|c|}
\hline \multicolumn{1}{|c|}{ Kategori } & Interval & f & \% \\
\hline Sangat rendah & $39,70<$ & 16 & 10 \\
\hline Rendah & $35,61-39,70$ & 34 & 22 \\
\hline Cukup & $31,51-35,61$ & 63 & 40 \\
\hline Tinggi & $27,41-31,51$ & 30 & 19 \\
\hline Sangat tinggi & $>27,41$ & 15 & 9 \\
\hline Total & 158 & 100 \\
\hline
\end{tabular}

Variabel kemampuan manajerial (X2) dengan indikator: keterampilan teknis; keterampilan konseptual; keterampilan interpersonal dan komunikasi; keterampilan pengambilan keputusan; dan keterampilan diagnostik dan analitik, diukur dengan 17 item. Hasil analisis data terhadap variabel tersebut menunjukkan nilai: mean $=54,66$; deviasi standar $=7,17$; skor maksimum $=68$; dan skor minimum $=27$. Berdasarkan hasil perhitungan dengan formula stanfive (Tabel 2) diperoleh distribusi frekuensi seperti pada Tabel 4. 
Tabel 4 Distribusi Frekuensi Variabel Kemampuan Manajerial (X2)

\begin{tabular}{|l|c|c|c|}
\hline \multicolumn{1}{|c|}{ Kategori } & Interval & f & \% \\
\hline Sangat rendah & $65,42<$ & 12 & 8 \\
\hline Rendah & $58,25-65,42$ & 30 & 19 \\
\hline Cukup & $51,08-58,25$ & 74 & 47 \\
\hline Tinggi & $43,91-51,08$ & 31 & 20 \\
\hline Sangat tinggi & $>43,91$ & 11 & 7 \\
\hline Total & 158 & 100 \\
\hline
\end{tabular}

Variabel efikasi diri (X3) dengan indikator: penguasaan pengalaman; pemodelan sosial; bujukan sosial; dan tanggapan psikologis, diukur dengan 13 item. Hasil analisis data terhadap variabel tersebut menunjukkan nilai: mean $=44,01$; deviasi standar $=5,20$; skor maksimum $=52$; dan skor minimum $=24$. Berdasarkan hasil perhitungan dengan formula stanfive (Tabel 2) diperoleh distribusi frekuensi seperti pada Tabel 5.

Tabel 5 Distribusi Frekuensi Variabel Efikasi Diri (X3)

\begin{tabular}{|l|c|c|c|}
\hline \multicolumn{1}{|c|}{ Kategori } & Interval & f & \% \\
\hline Sangat rendah & $51,81<$ & 12 & 8 \\
\hline Rendah & $46,61-51,81$ & 40 & 25 \\
\hline Cukup & $41,41-46,61$ & 60 & 38 \\
\hline Tinggi & $36,21-41,41$ & 39 & 25 \\
\hline Sangat tinggi & $>36,21$ & 7 & 4 \\
\hline Total & 158 & 100 \\
\hline
\end{tabular}

Variabel prestasi belajar mahasiswa (X4) diukur dari IPK yang diperoleh mahasiswa. Hasil analisis data terhadap variabel tersebut menunjukkan nilai: mean $=3,67$; deviasi standar $=0,21$; skor maksimum $=3,99$; dan skor minimum $=2,54$. Berdasarkan hasil perhitungan diperoleh distribusi frekuensi seperti pada Tabel 6.

Tabel 6 Distribusi Frekuensi Variabel Prestasi Belajar Mahasiswa (X4)

\begin{tabular}{|l|c|c|c|}
\hline \multicolumn{1}{|c|}{ Kategori } & Interval & f & \% \\
\hline Dengan pujian & $3,51-4,00$ & 135 & 85 \\
\hline Sangat memuaskan & $2,76-3,50$ & 22 & 14 \\
\hline Memuaskan & $2,00-2,75$ & 1 & 1 \\
\hline Total & 158 & 100 \\
\hline
\end{tabular}

Variabel kesiapan kerja mahasiswa (Y) dengan indikator: pengalaman sebelumnya; tingkat kematangan; keadaan mental dan emosi; kecerdasan; dan upaya pengembangan diri, diukur dengan 18 item. Hasil analisis data terhadap variabel tersebut menunjukkan nilai: mean $=59,75$; deviasi standar $=6,92$; skor maksimum $=72$; dan skor minimum $=32$. Berdasarkan hasil perhitungan dengan formula stanfive (Tabel 2) diperoleh distribusi frekuensi seperti pada Tabel 7.

Tabel 7 Distribusi Frekuensi Variabel Kesiapan Kerja Mahasiswa (Y)

\begin{tabular}{|l|c|c|c|}
\hline \multicolumn{1}{|c|}{ Kategori } & Interval & f & \% \\
\hline Sangat rendah & $70,14<$ & 7 & 4 \\
\hline Rendah & $63,22-70,14$ & 38 & 24 \\
\hline Cukup & $56,29-63,22$ & 70 & 44 \\
\hline Tinggi & $49,37-56,29$ & 34 & 22 \\
\hline Sangat tinggi & $>49,37$ & 9 & 6 \\
\hline Total & & 158 & 100 \\
\hline
\end{tabular}




\section{Uji Asumsi Data}

Sebelum data penelitian dianalisis dengan analisis regresi dan analisis jalur, data penelitian harus memenuhi asumsi data, yaitu data harus normal, homogen, linier, dan multikolinieritas. Uji normalitas dengan Kolmogorov-Smirnov diperoleh nilai probabilitas (asymp. sig.) variabel: gaya kepemimpinan $(X 1)=0,251$; kemampuan manajerial $(X 2)=0,074$; efikasi diri $(X 3)=0,363$; prestasi belajar mahasiswa $(X 4)=0,062$; dan kesiapan kerja mahasiswa $(Y)=0,107$. Berdasarkan hasil analisis diketahui bahwa kelima variabel nilai probabilitas $>0,05$ maka data dinyatakan berdistribusi normal.

Uji homonitas dengan Homogeneity of Variance Test diperoleh nilai probabilitas (asymp. sig.) variabel: gaya kepemimpinan $(X 1)=0,013$; kemampuan manajerial $(X 2)=0,001$; efikasi diri $(X 3)=$ 0,002 ; prestasi belajar mahasiswa $(\mathrm{X} 4)=0,037$; dan kesiapan kerja mahasiswa $(\mathrm{Y})=0,034$. Berdasarkan hasil analisis diketahui bahwa kelima variabel nilai probabilitas $<0,05$ maka data dinyatakan berasal dari data yang homogen.

Uji linieritas dengan Curve Estimation Test diperoleh nilai probabilitas (asymp. sig.) relasi variabel: gaya kepemimpinan $(\mathrm{X} 1)$ terhadap kesiapan kerja mahasiswa $(\mathrm{Y})=0,000$; kemampuan manajerial $(\mathrm{X} 2)$ terhadap kesiapan kerja mahasiswa $(\mathrm{Y})=0,000$; efikasi diri $(\mathrm{X} 3)$ terhadap kesiapan kerja mahasiswa $(Y)=0,000$; dan prestasi belajar mahasiswa $(X 4)$ terhadap kesiapan kerja mahasiswa $(Y)=0,019$. Berdasarkan hasil analisis diketahui bahwa keempat relasi variabel eksogen dan endogen memiliki nilai probabilitas $<0,05$ maka dapat dinyatakan hubungan variabel penelitian bersifat linier.

Uji multikolinieritas dengan nilai variance inflating factor (VIF) diperoleh VIF variabel: variabel: gaya kepemimpinan $(X 1)=1,391$; kemampuan manajerial $(X 2)=2,456$; efikasi diri $(X 3)=2,290$; dan prestasi belajar mahasiswa $(X 4)=1,042$. Nilai VIF variabel penelitian kurang dari 10. Sehingga dapat disimpulkan bahwa data dari variabel-variabel tersebut berasal dari populasi yang bebas dari kasus multikolinieritas. Penyajian hasil-hasil uji asumsi data yang meliputi uji normalitas, homogenitas, linieritas, dan multikolinieritas terhadap data penelitian, secara umum dapat dijelaskan bahwa data yang dianalisis telah memenuhi syarat untuk dianalisis dengan teknik analisis regresi dan analisis jalur (path analysis).

\section{Pengujian Hipotesis}

Hipotesis pertama yang diajukan menyatakan ada pengaruh yang signifikan gaya kepemimpinan (X1) terhadap kesiapan kerja mahasiswa ormawa (Y). Formula yang digunakan untuk menentukan ada pengaruh yang signifikan gaya kepemimpinan (X1) terhadap kesiapan kerja mahasiswa ormawa (Y) adalah rumus uji t. Hasil analisis uji t dengan bantuan program IBM SPSS Statistics 20 memperoleh nilai signifikansi sebesar 0,000 . Berdasarkan hasil analisis uji t dengan menggunakan taraf signifikansi 0,05 dapat diketahui bahwa nilai signifikansi yang diperoleh sebesar $0,000<0,05$. Sehingga $\mathrm{H} 0$ ditolak dan Ha diterima (Santoso, 2000). Hal ini berarti bahwa hipotesis yang menyatakan ada pengaruh yang signifikan gaya kepemimpinan (X1) terhadap kesiapan kerja mahasiswa ormawa (Y), diterima. Sehingga dapat disimpulkan bahwa terdapat pengaruh yang signifikan gaya kepemimpinan (X1) terhadap kesiapan kerja mahasiswa ormawa (Y).

Hipotesis kedua yang diajukan menyatakan ada pengaruh yang signifikan kemampuan manajerial (X2) terhadap kesiapan kerja mahasiswa ormawa (Y). Formula yang digunakan untuk menentukan ada pengaruh yang signifikan kemampuan manajerial (X2) terhadap kesiapan kerja mahasiswa ormawa (Y) adalah rumus uji t. Hasil analisis uji t dengan bantuan program IBM SPSS Statistics 20 memperoleh nilai signifikansi sebesar 0,000 . Berdasarkan hasil analisis uji t dengan menggunakan taraf signifikansi 0,05 dapat diketahui bahwa nilai signifikansi yang diperoleh sebesar $0,000<0,05$. Sehingga $\mathrm{H} 0$ ditolak dan Ha diterima (Santoso, 2000). Hal ini berarti bahwa hipotesis yang menyatakan ada pengaruh yang signifikan kemampuan manajerial (X2) terhadap kesiapan kerja mahasiswa ormawa (Y), diterima. Sehingga dapat disimpulkan bahwa terdapat pengaruh yang signifikan kemampuan manajerial (X2) terhadap kesiapan kerja mahasiswa ormawa (Y).

Hipotesis ketiga yang diajukan menyatakan ada pengaruh yang signifikan efikasi diri (X3) terhadap kesiapan kerja mahasiswa ormawa $(\mathrm{Y})$. Formula yang digunakan untuk menentukan ada pengaruh yang 
signifikan efikasi diri (X3) terhadap kesiapan kerja mahasiswa ormawa (Y) adalah rumus uji t. Hasil analisis uji $t$ dengan bantuan program IBM SPSS Statistics 20 memperoleh nilai signifikansi sebesar 0,000 . Berdasarkan hasil analisis uji t dengan menggunakan taraf signifikansi 0,05 dapat diketahui bahwa nilai signifikansi yang diperoleh sebesar $0,000<0,05$. Sehingga H0 ditolak dan Ha diterima (Santoso, 2000). Hal ini berarti bahwa hipotesis yang menyatakan ada pengaruh yang signifikan efikasi diri (X3) terhadap kesiapan kerja mahasiswa ormawa (Y), diterima. Sehingga dapat disimpulkan bahwa terdapat pengaruh yang signifikan efikasi diri (X3) terhadap kesiapan kerja mahasiswa ormawa (Y).

Hipotesis keempat yang diajukan menyatakan ada pengaruh yang signifikan prestasi belajar (X4) terhadap kesiapan kerja mahasiswa ormawa (Y). Formula yang digunakan untuk menentukan ada pengaruh yang signifikan prestasi belajar (X4) terhadap kesiapan kerja mahasiswa ormawa (Y) adalah rumus uji t. Hasil analisis uji $t$ dengan bantuan program IBM SPSS Statistics 20 memperoleh nilai signifikansi sebesar 0,019. Berdasarkan hasil analisis uji t dengan menggunakan taraf signifikansi 0,05 dapat diketahui bahwa nilai signifikansi yang diperoleh sebesar 0,019<0,05. Sehingga H0 ditolak dan Ha diterima (Santoso, 2000). Hal ini berarti bahwa hipotesis yang menyatakan ada pengaruh yang signifikan prestasi belajar (X4) terhadap kesiapan kerja mahasiswa ormawa (Y), diterima. Sehingga dapat disimpulkan bahwa terdapat pengaruh yang signifikan prestasi belajar (X4) terhadap kesiapan kerja mahasiswa ormawa (Y).

Hipotesis kelima yang diajukan menyatakan ada pengaruh yang signifikan gaya kepemimpinan (X1), kemampuan manajerial (X2), efikasi diri (X3), dan prestasi belajar (X4) terhadap kesiapan kerja mahasiswa ormawa $(\mathrm{Y})$. Formula yang digunakan untuk menentukan ada pengaruh yang signifikan gaya kepemimpinan (X1), kemampuan manajerial (X2), efikasi diri (X3), dan prestasi belajar (X4) terhadap kesiapan kerja mahasiswa ormawa (Y) adalah rumus uji F. Hasil analisis uji F dengan bantuan program IBM SPSS Statistics 20 memperoleh nilai signifikansi sebesar 0,000. Berdasarkan hasil analisis uji F dengan menggunakan taraf signifikansi 0,05 dapat diketahui bahwa nilai signifikansi yang diperoleh sebesar $0,000<0,05$. Sehingga H0 ditolak dan Ha diterima (Santoso, 2000). Hal ini berarti bahwa hipotesis yang menyatakan ada pengaruh yang signifikan gaya kepemimpinan (X1), kemampuan manajerial (X2), efikasi diri (X3), dan prestasi belajar (X4) terhadap kesiapan kerja mahasiswa ormawa (Y), diterima. Sehingga dapat disimpulkan bahwa terdapat pengaruh yang signifikan gaya kepemimpinan (X1), kemampuan manajerial (X2), efikasi diri (X3), dan prestasi belajar (X4) terhadap kesiapan kerja mahasiswa ormawa $(\mathrm{Y})$.

\section{Uji Persamaan Regresi}

Berdasarkan hasil besaran koefisien beta pada Tabel Coefficients kolom Unstandardized Coefficients $\mathrm{B}$, diperoleh formula persamaan garis regresi ganda antara variabel gaya kepemimpinan (X1), kemampuan manajerial (X2), efikasi diri (X3), dan prestasi belajar (X4) dengan kesiapan kerja mahasiswa ormawa $(\mathrm{Y})$, yaitu:

$$
\hat{\mathrm{Y}}=5,375+0,197 \mathrm{X} 1+0,217 \mathrm{X} 2+0,724 \mathrm{X} 3+1,102 \mathrm{X} 4
$$

Interpretasi model berdasarkan formula persamaan regresi tersebut adalah:

- Nilai a1 =0,197. Hal ini berarti jika nilai variabel gaya kepemimpinan (X1) meningkat satu satuan, sementara nilai variabel bebas lainnya bersifat tetap, maka tingkat variabel kesiapan kerja mahasiswa ormawa (Y) akan meningkat sebesar 0,197 satuan.

- Nilai a2 $=0,217$. Hal ini berarti jika nilai variabel kemampuan manajerial (X2) meningkat satu satuan, sementara nilai variabel bebas lainnya bersifat tetap, maka tingkat variabel kesiapan kerja mahasiswa ormawa (Y) akan meningkat sebesar 0,217 satuan.

- Nilai a3 $=0,724$. Hal ini berarti jika nilai variabel efikasi diri (X3) meningkat satu satuan, sementara nilai variabel bebas lainnya bersifat tetap, maka tingkat variabel kesiapan kerja mahasiswa ormawa (Y) akan meningkat sebesar 0,724 satuan.

- Nilai a4 = 1,102. Hal ini berarti jika nilai variabel prestasi belajar (X4) meningkat satu satuan, sementara nilai variabel bebas lainnya bersifat tetap, maka tingkat variabel kesiapan kerja mahasiswa 
ormawa (Y) akan meningkat sebesar 1,102 satuan.

- Nilai $\mathrm{k}=5,375$. Hal ini berarti jika variabel gaya kepemimpinan (X1), kemampuan manajerial (X2), efikasi diri (X3), dan prestasi belajar (X4) konstan, maka kesiapan kerja mahasiswa ormawa (Y) $=83,200$ satuan.

\section{Analisis Jalur}

Analisis jalur digunakan untuk menemukan penjelasan mengenai pola-pola hubungan langsung dan tidak langsung dari suatu model kausal yang disusun berdasarkan pertimbangan teoritis. Analisis jalur digunakan untuk mengetahui hubungan variabel eksogen yang satu dengan variabel eksogen yang lain, hingga hubungan dengan variabel endogen. Variabel eksogen dalam penelitian ini adalah gaya kepemimpinan (X1), kemampuan manajerial (X2), efikasi diri (X3), dan prestasi belajar (X4). Variabel endogen dalam penelitian ini adalah kesiapan kerja mahasiswa ormawa (Y). Selanjutnya hasil perhitungan analisis jalur dengan langkah-langkah kerja sebagai berikut:

\section{Ringkasan Koefisien Model Jalur}

\section{a. Model Jalur Struktur I}

Analisis regresi struktur pertama digunakan untuk menemukan koefisien beta dari hubungan variabel gaya kepemimpinan (X1) dengan kemampuan manajerial (X2). Hasil analisis dengan bantuan program IBM SPSS Statistics 20 memperoleh nilai: koefisien beta X1 sebesar 0,514; indeks determinasi (R2/Rsquare) sebesar 0,265; dan indeks error ( ) sebesar 0,857.

\section{b. Model Jalur Struktur II}

Analisis regresi struktur kedua digunakan untuk menemukan koefisien beta dari hubungan variabel gaya kepemimpinan (X1) dan kemampuan manajerial (X2) dengan efikasi diri (X3). Hasil analisis dengan bantuan program IBM SPSS Statistics 20 memperoleh nilai: koefisien beta X1 sebesar 0,102; koefisien beta X2 sebesar 0,692; indeks determinasi (R2/Rsquare) sebesar 0,562; dan indeks error ( ) sebesar 0,662 .

\section{c. Model Jalur Struktur III}

Analisis regresi struktur ketiga digunakan untuk menemukan koefisien beta dari hubungan variabel gaya kepemimpinan (X1), kemampuan manajerial (X2), dan efikasi diri (X3) dengan prestasi belajar (X4). Hasil analisis dengan bantuan program IBM SPSS Statistics 20 memperoleh nilai: koefisien beta X1 sebesar 0,083; koefisien beta X2 sebesar 0,065; koefisien beta X3 sebesar 0,089; indeks determinasi (R2/Rsquare) sebesar 0,040; dan indeks error ( ) sebesar 0,980.

\section{d. Model Jalur Struktur IV}

Analisis regresi struktur keempat digunakan untuk menemukan koefisien beta dari hubungan variabel gaya kepemimpinan (X1), kemampuan manajerial (X2), efikasi diri (X3), dan prestasi belajar (X4) dengan kesiapan kerja mahasiswa ormawa (Y). Hasil analisis dengan bantuan program IBM SPSS Statistics 20 memperoleh nilai: koefisien beta X1 sebesar 0,117; koefisien beta X2 sebesar 0,225; koefisien beta X3 sebesar 0,544; koefisien beta X4 sebesar 0,033; indeks determinasi (R2/Rsquare) sebesar 0,638; dan indeks error ( ) sebesar 0,602. Adapun ringkasan koefisien path (analisis jalur) dari hasil proses analisis regresi tiap struktur disajikan pada Tabel 8. 
Tabel 8 Ringkasan Koefisien Path

\begin{tabular}{|l|c|c|c|c|c|c|}
\hline \multicolumn{1}{|c|}{ Struktur } & Beta & Koefisien & Notasi & $\mathbf{R}^{2}$ & $\sqrt{1-\mathrm{R}^{2}}$ & $\begin{array}{c}\text { Pengaruh } \\
\text { Simultan }\end{array}$ \\
\hline Regresi I & $\mathrm{X} 1$ & 0,117 & $P X 2 \mathrm{X} 1$ & 0,265 & 0,857 & - \\
\hline Regresi II & $\mathrm{X} 2$ & 0,225 & PX3X1X2 & 0,562 & 0,662 & - \\
\hline Regresi III & $\mathrm{X} 3$ & 0,544 & $P Y X 1 X 2 \mathrm{X} 3$ & 0,040 & 0,980 & - \\
\hline Regresi IV & $\mathrm{X} 4$ & 0,033 & PYX1X2X3X4 & 0,638 & 0,602 & - \\
\hline$\varepsilon 1$ & - & 0,662 & - & - & - & - \\
\hline$\varepsilon 2$ & - & 0,980 & - & - & - & - \\
\hline$\varepsilon 3$ & - & 0,602 & - & - & - & - \\
\hline $\begin{array}{l}\mathrm{X} 1, \mathrm{X} 2, \mathrm{X} 3, \\
\text { dan X4 }\end{array}$ & - & - & - & - & - & 0,638 \\
\hline
\end{tabular}

\section{Ringkasan Signifikansi Koefisien Model Jalur (Beta) dan Uji Signifikansi}

\section{a. Ringkasan Signifikansi Koefisien Model Jalur (Beta)}

Adapun ringkasan signifikansi koefisien model jalur (beta) dari hasil proses analisis regresi tiap struktur pada Tabel 9.

Tabel 9 Signifikansi Tiap Koefisien Path

\begin{tabular}{|c|c|c|c|}
\hline Model Path & Koefisien & Nilai t & Sign. t \\
\hline PX2X1 & 0,117 & 6,023 & 0,000 \\
\hline PX3X1X2 & 0,225 & 4,827 & 0,000 \\
\hline PX4X1X2X3 & 0,544 & 20,400 & 0,000 \\
\hline PYX1X2X3X4 & 0,033 & 0,844 & 0,400 \\
\hline
\end{tabular}

\section{b. Uji Signifikansi (Uji t dan Uji F)}

Hasil analisis uji t Model Jalur Struktur I (parsial) dengan menggunakan taraf signifikansi 0,05 dapat diketahui bahwa nilai signifikansi yang diperoleh sebesar $0,000<0,05$. Hal ini berarti koefisien jalur signifikan. Sehingga dapat disimpulkan bahwa terdapat pengaruh yang signifikan gaya kepemimpinan (X1) terhadap kemampuan manajerial (X2).

Hasil analisis uji F Model Jalur Struktur II (simultan) dengan menggunakan taraf signifikansi 0,05 dapat diketahui bahwa nilai signifikansi yang diperoleh sebesar $0,000<0,05$. Hal ini berarti koefisien jalur signifikan. Sehingga dapat disimpulkan bahwa terdapat pengaruh yang signifikan gaya kepemimpinan (X1) dan kemampuan manajerial (X2) terhadap efikasi diri (X3).

Hasil analisis uji F Model Jalur Struktur III (simultan) dengan menggunakan taraf signifikansi 0,05 dapat diketahui bahwa nilai signifikansi yang diperoleh sebesar $0,007<0,05$. Hal ini berarti koefisien jalur signifikan. Sehingga dapat disimpulkan bahwa terdapat pengaruh yang signifikan gaya kepemimpinan (X1), kemampuan manajerial (X2), dan efikasi diri (X3) terhadap prestasi belajar (X4).

Hasil analisis uji F Model Jalur Struktur IV (simultan) dengan menggunakan taraf signifikansi 0,05 dapat diketahui bahwa nilai signifikansi yang diperoleh sebesar $0,000<0,05$. Hal ini berarti koefisien jalur signifikan. Sehingga dapat disimpulkan bahwa terdapat pengaruh yang signifikan gaya kepemimpinan (X1), kemampuan manajerial (X2), efikasi diri (X3), dan prestasi belajar (X4) terhadap kesiapan kerja mahasiswa ormawa (Y).

Berdasarkan pengujian keseluruhan model jalur secara statistik signifikan, sehingga disimpulkan bahwa variabel eksogen berkontribusi secara simultan dan signifikan terhadap variabel endogen. Model empirik variabel eksogen dan endogen juga signifikan dan memiliki hubungan. 


\section{Model Empirik}

Bentuk model empirik hubungan kausal variabel penelitian pada Gambar 5.

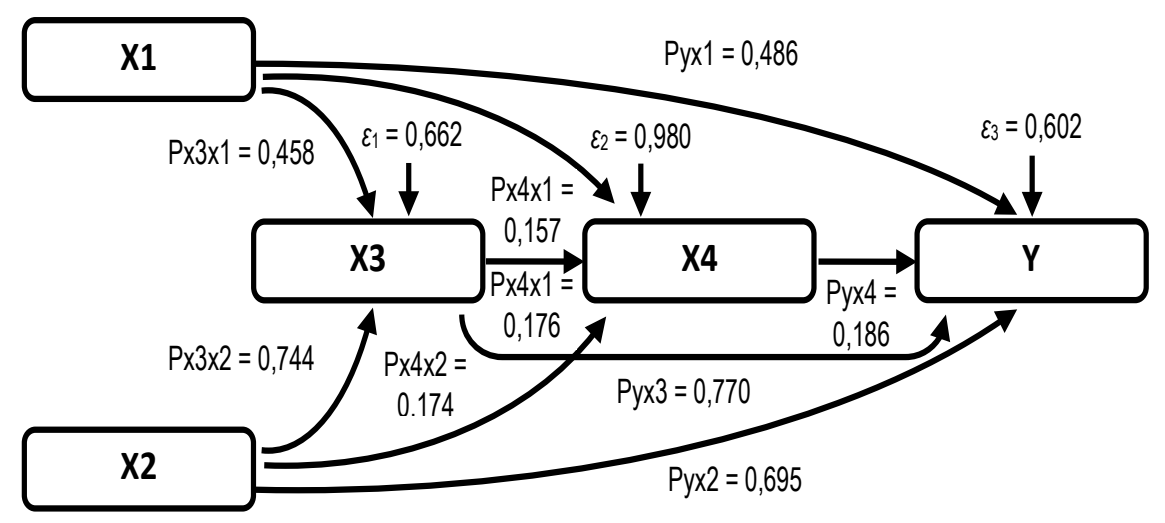

Gambar 5 menunjukkan bahwa koefisien regresi variabel efikasi diri $(\mathrm{X} 3)(\mathrm{PYX} 3=0,770)$ besar dari pada koefisien variabel kemampuan manajerial (X2) (PYX2 =0,695); gaya kepemimpinan (X1) $(\mathrm{PYX} 1=0,486)$; dan prestasi belajar $(\mathrm{X} 4)(\mathrm{PYX} 4=0,186)$. Sehingga dapat disimpulkan bahwa efikasi diri (X3) akan meningkatkan kesiapan kerja mahasiswa ormawa (Y) dengan dilandasi oleh kemampuan manajerial (X2); gaya kepemimpinan (X1); dan prestasi belajar (X4). Efikasi diri (X3) merupakan determinan utama bagi kesiapan kerja mahasiswa ormawa $(\mathrm{Y})$ yang dilandasi oleh kemampuan manajerial (X2); gaya kepemimpinan (X1); dan prestasi belajar (X4).

\section{Ringkasan Koefisien Hubungan Langsung dan Tidak Langsung}

Koefisien hubungan langsung variabel penelitian yakni: PYX1 sebesar 0,486; PYX2 sebesar 0,695; PYX3 sebesar 0,770; PYX4 sebesar 0,186; PX2X1 sebesar 0,514; PX3X1 sebesar 0,458; PX4X1 sebesar 0,157; PX3X2 sebesar 0,744; PX4X2 sebesar 0,174; dan PX4X3 sebesar 0,176. Adapun koefisien tidak langsung yakni:

a. Hubungan tidak langsung X1 dengan Y melalui X2 sebesar PX2X1.PYX2 $=(0,514) \cdot(0,695)=0,357$;

b. Hubungan tidak langsung X1 dengan $Y$ melalui X3 sebesar PX3X1.PYX3 $=(0,458) \cdot(0,770)=0,353$;

c. Hubungan tidak langsung X1 dengan Y melalui X4 sebesar PX4X1.PYX4 $=(0,157) \cdot(0,186)=0,029$;

d. Hubungan tidak langsung X2 dengan Y melalui X3 sebesar PX3X2.PYX2 $=(0,744) \cdot(0,695)=0,518$;

e. Hubungan tidak langsung X2 dengan Y melalui X4 sebesar PX4X2.PYX2 $=(0,174) \cdot(0,695)=0,121$;

f. Hubungan tidak langsung X3 dengan Y melalui X4 sebesar PX4X3.PYX3 $=(0,176) \cdot(0,770)=0,136$.

Adapun ringkasan koefisien hubungan langsung dan tidak langsung variabel eksogen dan endogen pada Tabel 10.

Tabel 10 Hubungan Langsung dan Tidak Langsung Variabel

\begin{tabular}{|c|c|c|c|c|c|c|c|}
\hline \multirow{3}{*}{$\begin{array}{l}\text { Variabel Eksogen } \\
\text { (X) }\end{array}$} & \multirow{3}{*}{$\begin{array}{l}\text { Koefisien } \\
\text { jalur }\end{array}$} & \multicolumn{5}{|c|}{ Hubungan dengan Variabel Endogen (Y) } & \multirow{3}{*}{$\begin{array}{r}\text { Pengaruh } \\
\text { Simultan } \\
\end{array}$} \\
\hline & & \multirow{2}{*}{ Langsung } & \multicolumn{3}{|c|}{ Tidak Langsung (melalui) } & \multirow[t]{2}{*}{ Total } & \\
\hline & & & $\mathrm{X} 2$ & $\mathrm{X} 3$ & $\mathrm{X} 4$ & & \\
\hline $\mathrm{X} 1$ & 0,117 & 0,117 & 0,357 & 0,353 & 0,029 & 0,856 & - \\
\hline $\mathrm{X} 2$ & 0,225 & 0,225 & - & 0,518 & 0,121 & 0,864 & - \\
\hline $\mathrm{X} 3$ & 0,544 & 0,544 & - & - & 0,136 & 0,680 & - \\
\hline $\mathrm{X} 4$ & 0,033 & 0,033 & - & - & - & 0,033 & - \\
\hline$\varepsilon_{1}$ & 0,662 & - & - & - & - & - & - \\
\hline 52 & 0,980 & $\overline{-}$ & $\overline{-}$ & - & $\overline{-}$ & - & - \\
\hline$\varepsilon_{3}$ & 0,602 & - & - & - & - & - & - \\
\hline $\mathrm{X} 1, \mathrm{X} 2, \mathrm{X} 3$, dan X4 & - & - & - & - & - & - & 0,638 \\
\hline
\end{tabular}

Berdasarkan Tabel 10 dapat dijelaskan hasil temuan penelitian bahwa:

a. Variabel gaya kepemimpinan (X1) memiliki determinasi (sumbangan efektif) terhadap kesiapan kerja mahasiswa ormawa (Y). Dengan demikian tinggi rendahnya kesiapan kerja mahasiswa ormawa 
(Y) dapat dijelaskan oleh gaya kepemimpinan (X1), secara langsung sebesar 0,117;

b. Variabel kemampuan manajerial (X2) memiliki determinasi (sumbangan efektif) terhadap kesiapan kerja mahasiswa ormawa $(\mathrm{Y})$. Dengan demikian tinggi rendahnya kesiapan kerja mahasiswa ormawa (Y) dapat dijelaskan oleh kemampuan manajerial (X2), secara langsung sebesar 0,225;

c. Variabel efikasi diri (X3) memiliki determinasi (sumbangan efektif) terhadap kesiapan kerja mahasiswa ormawa (Y). Dengan demikian tinggi rendahnya kesiapan kerja mahasiswa ormawa (Y) dapat dijelaskan oleh efikasi diri (X3), secara langsung sebesar 0,544;

d. Variabel prestasi belajar (X4) memiliki determinasi (sumbangan efektif) terhadap kesiapan kerja mahasiswa ormawa (Y). Dengan demikian tinggi rendahnya kesiapan kerja mahasiswa ormawa (Y) dapat dijelaskan oleh prestasi belajar (X4), secara langsung sebesar 0,033;

e. Variabel gaya kepemimpinan (X1) memiliki determinasi (sumbangan efektif) terhadap kesiapan kerja mahasiswa ormawa (Y) melalui kemampuan manajerial (X2), efikasi diri (X3), dan prestasi belajar (X4). Dengan demikian tinggi rendahnya kesiapan kerja mahasiswa ormawa (Y) dijelaskan oleh gaya kepemimpinan (X1) melalui kemampuan manajerial (X2), efikasi diri (X3), dan prestasi belajar (X4), secara tidak langsung sebesar 0,856 .

\section{Indeks Determinasi}

Maksud dari interpretasi indeks determinasi adalah mengungkapkan urutan variabel yang memiliki kontribusi (determinasi efektif) besar terhadap mutu pendidikan sekolah. Untuk menjawab persoalan yang dimaksud, hasil determinasi analisis jalur berdasarkan pengolahan data pada Tabel 11 .

Tabel 11 Indeks Determinasi Tiap Variabel Eksogen terhadap Endogen

\begin{tabular}{|c|c|c|c|c|}
\hline Variabel & Beta & rywi & $\begin{array}{c}\text { Determinasi } \\
\text { (efektif) }\end{array}$ & $\begin{array}{c}\text { Pengaruh } \\
\text { Simultan }\end{array}$ \\
\hline $\mathrm{X} 1$ & 0,117 & 0,486 & 0,057 & - \\
\hline $\mathrm{X} 2$ & 0,225 & 0,695 & 0,156 & - \\
\hline $\mathrm{X} 3$ & 0,544 & 0,770 & 0,419 & - \\
\hline $\mathrm{X} 4$ & 0,033 & 0,186 & 0,006 & - \\
\hline $\mathrm{X} 1, \mathrm{X} 2, \mathrm{X} 3$, dan X4 & - & - & - & 0,638 \\
\hline
\end{tabular}

Berpedoman pada Tabel 11 dapat dijelaskan bahwa indeks determinasi (sumbangan efektif) terhadap kesiapan kerja mahasiswa ormawa (Y) adalah gaya kepemimpinan (X1) sebesar 5,7\%; kemampuan manajerial (X2) sebesar 15,6\%; efikasi diri (X3) sebesar 41,9\%; dan prestasi belajar (X4) sebesar 0,6\%. Indeks determinasi variabel eksogen secara simultan memengaruhi variabel endogen sebesar $63,8 \%$ dan sisanya sebesar $(\varepsilon 3) 2.100 \%=(0,602) 2.100 \%=0,362.100 \%=36,2 \%$ (Riduwan dan Kuncoro, 2017) merupakan kontribusi variabel lain di luar penelitian ini. Perhitungan indeks determinasi (sumbangan efektif) variabel penelitian diinterpretasikan pada Gambar 6.

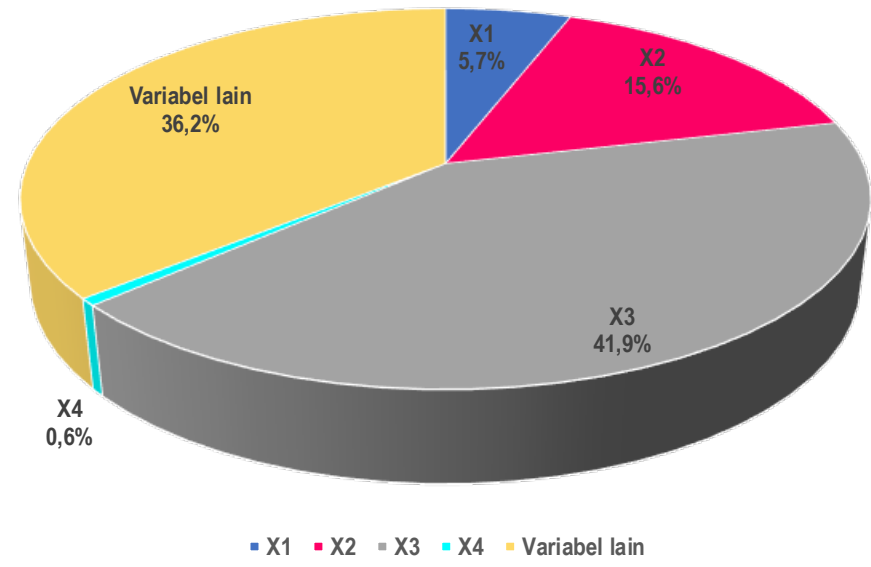

Gambar 6 Diagram Persentase Sumbangan Efektif Variabel Penelitian (X1, X2, X3, dan X4) dan Variabel Lain terhadap Variabel Y 


\section{PEMBAHASAN}

\section{Pengaruh Gaya Kepemimpinan (X1) terhadap Kesiapan Kerja Mahasiswa Ormawa (Y)}

Penelitian ini menyimpulkan ada pengaruh yang signifikan gaya kepemimpinan (X1) terhadap kesiapan kerja mahasiswa ormawa (Y). Hasil penelitian ini selaras dengan hasil penelitian Nurahman (2017) yang menyimpulkan variabel gaya kepemimpinan memiliki pengaruh yang signifikan terhadap kesiapan kerja. Penelitian Fox (2018) menyimpulkan pengembangan kepemimpinan diperlukan untuk menyiapkan karier peserta didik pada masa depan. Perguruan tinggi memiliki kewajiban mempersiapkan mahasiswa untuk kesiapan karier dengan memanfaatkan program pengembangan kepemimpinan untuk lebih mengembangkan pengetahuan, keterampilan, dan kompetensi yang diterjemahkan ke dunia kerja yang terus berubah, terutama bagi lulusan yang sedang dalam transisi ke pekerjaan pertama mereka.

Universitas dapat menjaring harapan pengusaha untuk lulusan perguruan tinggi yang barubaru ini dalam keadaan pendidikan tinggi saat ini, kompetensi kesiapan karier yang dihasilkan yang dikembangkan oleh perguruan tinggi dan pengusaha (Cruzvergara, dkk., 2018; Sultoni, dkk., 2018a), dan meningkatnya pergeseran bagi perguruan tinggi dan universitas untuk mengakui kesiapan karier sebagai prioritas kelembagaan. Dalam rangka mempersiapkan mahasiswa untuk karier masa depan mereka, penting untuk memahami kompetensi yang diperlukan untuk kesuksesan karier. Kompetensi kepemimpinan dapat digunakan untuk membantu meningkatkan kesiapan karier mahasiswa (Seemiller, 2018; Sobri, dkk., 2019; Sultoni, dkk., 2018b).

Peck (2018) berdasarkan penelitiannya menyimpulkan program pengembangan kepemimpinan yang pernah diikuti mahasiswa merupakan aspek yang paling diminati oleh pengusaha ketika akan menerima calon pegawai. Selain itu, kebutuhan untuk memetakan secara holistik dan mengintegrasikan keterampilan karier yang diperoleh dalam konteks kurikuler dan kokurikuler harus dieksplorasi, dengan model kepemimpinan yang disediakan oleh perguruan tinggi untuk menerapkan pendekatan ini. Lembaga pendidikan tinggi perlu menyelaraskan pengembangan kepemimpinan dan kesiapan karier mahasiswa (Jaunarajs \& McGarry, 2018; Sultoni, dkk., 2019; Gunawan, dkk., 2017a; Pambudi \& Gunawan, 2019; Saputra, dkk., 2019). Praktik terbaik untuk integrasi strategis pengembangan kepemimpinan dengan pengembangan karier yang mempromosikan kesiapan karier mahasiswa sebaiknya disertakan.

\section{Pengaruh Kemampuan Manajerial (X2) terhadap Kesiapan Kerja Mahasiswa Ormawa} (Y)

Penelitian ini menyimpulkan ada pengaruh yang signifikan kemampuan manajerial (X2) terhadap kesiapan kerja mahasiswa ormawa (Y). Hasil penelitian ini selaras dengan penelitian yang dilakukan oleh Bandaranaike \& Willison (2015) yang menyimpulkan bahwa universitas sebaiknya membekali mahasiswa suatu program manajemen organisasi yang di dalamnya membekali kemampuan manajerial mahasiswa, sehingga mereka dapat memperoleh keterampilan ketenagakerjaan yang lengkap, jika tidak sepenuhnya dikembangkan melalui pengalaman kerja yang relevan. Dunia kerja semakin berubah, dan untuk mengikuti perubahan, organisasi merekrut lulusan baru dengan tujuan memfasilitasi pertumbuhan dan peningkatan berkelanjutan.

Tantangannya adalah bahwa lulusan ini tidak memiliki jenis kompetensi yang dibutuhkan untuk bertahan di lingkungan kerja (Mashigo, 2014; Gabric \& McFadden, 2001). Ada banyak tantangan dalam lingkungan kerja yang dapat mempengaruhi kinerja lulusan, dan ini membutuhkan kompetensi tertentu yang jarang dimiliki lulusan. Kemampuan manajerial merupakan hal penting yang harus dimiliki di dunia kerja (Braverman, 2018; Mashigo, 2014). Persepsi kesiapan kerja didasarkan pada kerangka kerja kebutuhan organisasi yang telah dipengaruhi secara signifikan dalam beberapa tahun terakhir oleh perubahan dalam lingkungan kompetitif, dalam teknologi, dan kemampuan manajerial (Arnold \& Mackenzie-Davey, 1992; Bills, 1998; Leveson, 2000). Pengusaha melihat perguruan tinggi sebagai institusi yang bertanggung jawab untuk mempersiapkan mahasiswa untuk pekerjaan produktif.

Perubahan dalam teknologi, praktik manajerial, dan lingkungan kompetitif telah meningkatkan tingkat dan luasnya pengetahuan, keterampilan, dan kemampuan yang dibutuhkan pengusaha dari 
karyawan. Ini semakin memperlebar kesenjangan yang sudah signifikan antara kebutuhan pemberi kerja dan tingkat keterampilan serta kemampuan para lulusan yang memasuki kolam tenaga kerja (Leveson, 2000; Gunawan, dkk., 2017b). Pengusaha mengakui bahwa beberapa bentuk pelatihan paling baik dilakukan di tempat kerja dan jangan berharap perguruan tinggi menghasilkan mahasiswa dengan keterampilan kerja tertentu. Namun, pengusaha berharap perguruan tinggi menghasilkan mahasiswa dengan kemampuan manajerial untuk menggunakan pengetahuan umum dan dengan keterampilan akademik, seperti membaca, matematika, menulis, komunikasi lisan, dan pemecahan masalah (Tschirgi, 1972). Pengusaha juga ingin perguruan tinggi mempersiapkan mahasiswa dengan karakteristik umum yang meningkatkan kinerja, seperti kemampuan untuk bekerja secara produktif dengan orang lain dan menunjukkan inisiatif dan tanggung jawab.

\section{Pengaruh Efikasi Diri (X3) terhadap Kesiapan Kerja Mahasiswa Ormawa (Y)}

Penelitian ini menyimpulkan ada pengaruh yang signifikan efikasi diri (X3) terhadap kesiapan kerja mahasiswa ormawa (Y). Makki, dkk., (2016) berdasarkan hasil penelitiannya menyimpulkan seseorang agar dapat dipekerjakan (mendapatkan pekerjaan baru) dan mencapai prestasi tertentu, harus memiliki kepercayaan diri pada kompetensi yang ia miliki untuk mencapai tujuan organisasi yang ditetapkan. Revolusi industri dan globalisasi mengharapkan lulusan untuk menjadi terampil dan diperlengkapi sebelum masuk ke tempat kerja. Oleh sebab itu, lulusan perguruan tinggi harus mampu mengeksplorasi karir dan keterampilan mereka, serta meningkatkan kepercayaan diri. Kenyataannya, kesulitan yang dihadapi lulusan pada tingkat awal karier secara negatif memengaruhi tingkat kepercayaan diri mereka (Makki, dkk., 2015; Doe, 2015).

Penelitian Anthony (2005) dengan menggunakan desain penelitian korelasional, menyimpulkan ada hubungan positif efikasi diri yang dirasakan mahasiswa dengan faktor-faktor terpilih lainnya terhadap kesiapan kerja. Efikasi diri dapat menjadi alat yang berguna ketika menilai kesiapan kerja. Temuan yang diungkapkan dalam penelitian Anthony (2005) berada dalam arah yang positif dapat berkontribusi untuk memahami perilaku dan kinerja terkait pekerjaan tertentu. Mengingat temuan dalam penelitian ini informatif, ketika meninjau hasil, orang harus sadar, bahwa beberapa kasus faktor lingkungan dapat memfasilitasi atau menghambat kinerja tergantung pada tempat kerja yang berbeda dan iklim kerja.

Simpulan penelitian Tentama, dkk., (2019) adalah efikasi diri dapat memprediksi kesiapan kerja. Studi Yi-Li \& Goh (2011) meneliti peran efikasi diri pada kesiapan kerja dan pilihan karir di kalangan pemuda di Singapura. Hasil penelitian Yi-Li \& Goh (2011) menunjukkan bahwa efikasi diri sangat terkait dengan kesiapan kerja. Responden juga diminta untuk menunjukkan pilihan karir mereka dan memberikan karakteristik demografis mereka melalui kuesioner semi-terstruktur. Temuan-temuan penelitian memberi para pendidik khusus dan profesional rehabilitasi kejuruan dengan informasi tentang pentingnya efikasi diri dan disarankan untuk intervensi yang bertujuan mengembangkan efikasi untuk meningkatkan kesiapan kerja mereka. Percaya bahwa seseorang dapat berhasil dalam upaya pendidikan dan memiliki karier yang bermakna adalah tujuan penting bagi semua mahasiswa, dan perguruan tinggi yang diposisikan untuk meningkatkan kepercayaan ini (Baker, dkk., 2017).

\section{Pengaruh Prestasi Belajar (X4) terhadap Kesiapan Kerja Mahasiswa Ormawa (Y)}

Penelitian ini menyimpulkan ada pengaruh yang signifikan prestasi belajar (X4) terhadap kesiapan kerja mahasiswa ormawa (Y). Hasil penelitian ini selaras dengan hasil penelitian Faizah \& Indrawati (2017) yang menyimpulkan ada hubungan positif prestasi belajar yang diraih oleh peserta didik dengan kesiapan kerjanya. Hansen \& Hoag (2018) berdasarkan hasil penelitiannya menyarankan kepada perguruan tinggi untuk menciptakan lingkungan belajar agar dapat meningkatkan prestasi belajar mahasiswa dan pada akhirnya berkontribusi pada keberhasilan mahasiswa, pengembangan kepemimpinan, dan kesiapan karier.

Kesiapan kerja mahasiswa memiliki peran penting memasuki dunia kerja dan prestasi belajar mahasiswa memiliki hubungan positif pada kesiapan kerja mahasiswa (Yuliani \& Yuniarsih, 2019; 
Sumarsono, dkk., 2019). Prestasi belajar mahasiswa dapat diasumsikan memiliki keterkaitan dengan kebutuhan berprestasi. Perguruan tinggi dan dunia usaha perlu memastikan tak adanya kesenjangan prestasi yang diraih mahasiswa dengan kesiapan kerja. Sehingga posisi di perusahaan memang benarbenar diisi oleh orang-orang yang berprestasi. Tidak hanya ada kesenjangan antara pendidikan dan karir mereka, tetapi perguruan tinggi dan pengusaha harus mampu menerjemahkan prestasi akademik menjadi kesiapan kerja dan kesuksesan karir (Grummon, 1997; Doe, 2015; Prastiawan, dkk., 2019; Putri, dkk., 2019). Selain itu, standar dan tolok ukur keterampilan kesiapan kerja yang diperlukan untuk sukses di tempat kerja sangat sedikit dan disalahpahami sebagai yang terbaik (Doe, 2015; ACT, 2013; Nurabadi, dkk., 2019b).

Komarraju, dkk., (2010) dalam penelitian mereka menyimpulkan bahwa ketika mahasiswa berinteraksi dengan kampus dalam berbagai cara, itu mengarah pada pencapaian akademik, terutama di luar kelas. Temuan ini juga konsisten dengan temuan sebelumnya oleh Lundberg \& Schreiner (2004) bahwa hasil belajar mahasiswa yang lebih baik dapat ditelusuri ke mahasiswa yang memiliki interaksi positif dengan kampus mereka. Implikasi dari temuan ini adalah bahwa keahlian dan kehadiran kampus tidak hanya berharga bagi mahasiswa, tetapi juga membangun keandalan diri mahsiswa. Perguruan tinggi di sebagian besar budaya dianggap sangat dihargai dan mahasiswa yang memiliki keamanan dukungan kampus mencapai lebih banyak hal di banyak bidang, seperti publikasi, presentasi makalah penelitian dan pengajaran.

\section{Pengaruh Gaya Kepemimpinan (X1), Kemampuan Manajerial (X2), Efikasi Diri (X3), dan Prestasi Belajar (X4) terhadap Kesiapan Kerja Mahasiswa Ormawa (Y)}

Penelitian ini menyimpulkan ada pengaruh yang signifikan gaya kepemimpinan (X1), kemampuan manajerial (X2), efikasi diri (X3), dan prestasi belajar (X4) terhadap kesiapan kerja mahasiswa ormawa (Y). Machida \& Schaubroeck (2011) dalam penelitiannya berusaha untuk menggambarkan peran beragam efikasi diri dalam pengembangan kepemimpinan. Peran ini lebih kompleks daripada yang telah dikonseptualisasikan dalam penelitian masa lalu dan karya teoritis. Gambaran mengenai kemampuan pemimpin, seperti disampaikan oleh orang lain seperti sebagai mentor dan pengembang dan ditafsirkan oleh para pemimpin ketika mereka mengalami keberhasilan dan kegagalan, adalah penting untuk pengembangan para pemimpin yang sangat efektif.

Mungkin klise bahwa para pemimpin secara konstan dituntut untuk belajar dan berkembang di dunia yang berubah dengan cepat ini. Tetapi untuk memahami kebenaran ini membutuhkan proses perkembangan yang melengkapi perbedaan antara situasi persiapan para pemimpin dan situasi kinerja mereka, mengidentifikasi faktor-faktor pribadi dan kontekstual yang memengaruhi keyakinan efikasi para pemimpin, dan mengintegrasikan perspektif beragam aspek dari para pemimpin. Keefektifan pemimpin dengan cara yang mempromosikan lintasan pembelajaran positif yang berkelanjutan. Hal yang sama dapat dikatakan untuk penelitian tentang pengembangan pemimpin, karena harus mendapatkan pengetahuan lebih lanjut di masing-masing bidang ini. Temuan dari penelitian Machida \& Schaubroeck (2011) memberikan informasi kerangka kerja yang harus mendorong praktik yang lebih efektif menyeimbangkan kebutuhan para pemimpin untuk tampil dalam jangka pendek dengan keharusan yang mereka pelajari dan adaptif dalam jangka panjang.

Tamrat (2019) menyatakan keterampilan khusus dan atribut yang disarankan sebagai komponen penting dari kesiapan kerja dan telah diidentifikasi secara luas yaitu: keterampilan komunikasi, pemikiran kritis dan analitis, kerja tim, penyelesaian masalah, manajemen diri, kesadaran bisnis dan pelanggan, mengambil inisiatif, kepemimpinan dan kemampuan manajerial, pemikiran sistem, dan etos kerja. Keberlangsungan kerja lulusan yang sukses dan sesuai adalah manfaat bagi semua pemangku kepentingan (lulusan, pemberi kerja, lembaga pendidikan tinggi, pemerintah, dan ekonomi pada umumnya). Di sisi lain, kegagalan untuk membekali lulusan dengan keterampilan ini dapat memiliki konsekuensi yang merugikan bagi karyawan, pengusaha, organisasi, dan ekonomi pada umumnya karena dapat menjeda tantangan terkait pengangguran, upah rendah, kepuasan kerja, kemampuan untuk menemukan tenaga kerja yang cocok dan keseluruhan produktivitas dan daya saing ekonomi tertentu. 
Meskipun akan lebih tepat bagi semua pemangku kepentingan untuk bergabung bersama untuk meningkatkan kelulusan kerja, tampaknya ada permintaan yang sangat besar terhadap institusi pendidikan tinggi untuk menghasilkan lulusan dengan profil yang dibutuhkan industri tanpa berbagi tanggung jawab untuk tujuan itu. Ekspektasi institusi pendidikan tinggi yang dilebih-lebihkan ini terkadang mengabaikan pentingnya komitmen dari para pemangku kepentingan penting lainnya seperti pengusaha dan siswa, yang menghasilkan peran pasif mereka yang dapat berdampak buruk pada kesuksesan. Jika diserahkan secara eksklusif kepada institusi pendidikan tinggi, tujuan akan tetap sulit dicapai. Oleh karena itu, pergeseran sikap diperlukan untuk membawa perubahan di mana pemangku kepentingan yang penting memikul berbagai peran dalam mengidentifikasi keterampilan kerja, meningkatkan mobilitas lulusan dan fakultas universitas, dan memfasilitasi fase transisi untuk lulusan baru.

Diskusi yang lebih luas tentang kelulusan kerja mengasumsikan bahwa lulusan harus mengembangkan keterampilan dan atribut yang merespons lingkungan kerja yang cepat berubah saat ini. Institusi pendidikan tinggi biasanya dibiarkan mendefinisikan dan memberikan keterampilan ini dan memasukkannya ke dalam program mereka. Sementara peran institusi pendidikan tinggi dalam mempersiapkan lulusan yang berkualitas tidak dapat diabaikan, peran ini tidak dapat diselesaikan secara tunggal tanpa membawa pengusaha dan yang lainnya. Namun, paling sering, peran pengusaha dalam mengembangkan keterampilan tersebut tampaknya merupakan elemen yang hilang atau masalah yang diabaikan.

Penting untuk dicatat bahwa banyak keterampilan generik yang dibutuhkan dapat berbeda dari satu konteks geografis atau industri ke konteks lainnya. Walaupun identifikasi keterampilan atau kompetensi terkait ketenagakerjaan spesifik telah dilakukan di banyak negara, seperti Australia, Selandia Baru, Inggris, dan Amerika Serikat, kenyataannya berbeda dalam konteks di mana latihan ini tidak ada (Tamrat, 2019). Dengan tidak adanya kerangka kerja, definisi keterampilan dan kompetensi yang dapat dipekerjakan tidak dapat diserahkan kepada perguruan tinggi. Ini harus dikembangkan melalui partisipasi aktif dari pengusaha yang harus mengambil peran dengan jelas mengartikulasikan apa yang mereka harapkan dari lulusan baru. Pembaruan keterampilan yang dibutuhkan oleh lulusan secara terus menerus juga harus dilakukan melalui keterlibatan pengusaha yang terus-menerus yang lebih sadar akan perubahan tuntutan di lingkungan kerja.

Selain keterlibatan pengusaha dalam desain kurikulum, bantuan mereka dalam menciptakan peluang untuk pembelajaran pengalaman (praktik kerja industri) adalah kuncinya (Faizah \& Indrawati, 2017; Tentama, dkk., 2019). Magang mahasiswa tampaknya menjadi kegiatan umum di universitas di seluruh dunia untuk mengekspos mahasiswa ke dunia kerja. Praktik ini menuntut keterlibatan aktif dari pemberi kerja dalam menugaskan mahasiswa magang ke tempat kerja yang sesuai, memberikan mereka dukungan, dan memonitor kinerja mereka. Program pembelajaran pengalaman berhasil tidak hanya ketika pengusaha memberikan izin untuk penempatan mahasiswa, tetapi yang lebih penting ketika mereka terlibat dalam memantau kemajuan mahasiswa dan memberikan umpan balik yang membangun. Namun, dalam banyak konteks tingkat partisipasi pemberi kerja ini tetap pasif. Di mana hal itu terjadi, keberhasilan program eksternal di mana staf universitas tinggal di penempatan industri untuk memperoleh pengalaman praktis membutuhkan tingkat kemauan, bantuan, tindak lanjut dan umpan balik yang serupa.

Peran industri dan bisnis selama fase awal pekerjaan lulusan juga merupakan komponen penting dalam meningkatkan keterampilan kerja karyawan muda. Secara tradisional, pengusaha mengasumsikan peran untuk mendidik lulusan baru untuk menjadi anggota yang produktif dari angkatan kerja yang diberikan. Peran ini berangsur-angsur terkikis, karena pengusaha ingin agar lulusan datang "siap pakai" dengan keterampilan yang dibutuhkan atau dengan beberapa tahun pengalaman kerja. Keduanya tidak realistis dan dapat merugikan sebagian besar lulusan muda yang tidak dapat memenuhi harapan atau persyaratan ini.

Kesiapan pengusaha untuk memikul tanggung jawab selama fase awal kehidupan kerja lulusan muda tidak hanya membantu lulusan baru untuk mengembangkan keterampilan baru tetapi juga untuk mengembangkan kepercayaan diri yang akan membantu mereka menanggapi berbagai tuntutan 
pekerjaan mereka. Ini mengharuskan pengusaha mencurahkan waktu dan sumber daya untuk tugas itu. Penelitian di bidang ini menunjukkan bahwa pengusaha yang paling berhasil dalam mengembangkan keterampilan kerja lulusan muda adalah mereka yang menciptakan peluang tambahan untuk belajar, seperti lingkungan yang kurang ramah bagi karyawan muda dapat menurunkan kapasitas belajar, kepercayaan diri, dan hasil (Tamrat, 2019; Nurabadi, dkk., 2019a).

Karena kesiapan kerja melibatkan berbagai dimensi intelektual, sosial, dan pribadi yang berkembang baik selama tahun-tahun universitas dan di tempat kerja, pengembangan keterampilan kerja tidak dapat diserahkan secara eksklusif ke universitas. Memang benar bahwa universitas memiliki tanggung jawab untuk reformasi kurikulum yang akan lebih mempersiapkan lulusan untuk tuntutan yang semakin kompleks dari tempat kerja. Tetapi keberhasilan mereka tergantung pada pemangku kepentingan lainnya yang sama-sama berkomitmen. Manfaat bagi pengusaha akan ditentukan tidak hanya oleh seberapa banyak universitas beradaptasi, tetapi juga oleh kesiapan, kapasitas, dan upaya mereka sendiri untuk berkontribusi.

Pengusaha tidak dapat mengeluh tentang lulusan muda yang "setengah matang" jika mereka sendiri tetap berada di luar proses pendidikan dan pelatihan. Penting untuk bergerak melampaui meratapi keterampilan lulusan yang terbatas dan mengambil peran proaktif dalam mempengaruhi dan berkontribusi pada hasil universitas. Sementara universitas memiliki peran besar dalam perubahan ini, keterlibatan aktif pemerintah sangat penting di banyak lingkungan untuk menetapkan arah kebijakan, menggembleng keterlibatan multi-pemangku kepentingan dan menawarkan insentif langsung dan tidak langsung kepada perusahaan yang terlibat dalam inisiatif ini.

\section{SIMPULAN}

Berdasarkan hasil analisis data, penelitian ini menyimpulkan: (1) ada pengaruh yang signifikan gaya kepemimpinan (X1) terhadap kesiapan kerja mahasiswa ormawa (Y); (2) ada pengaruh yang signifikan kemampuan manajerial (X2) terhadap kesiapan kerja mahasiswa ormawa (Y); (3) ada pengaruh yang signifikan efikasi diri (X3) terhadap kesiapan kerja mahasiswa ormawa (Y); (4) ada pengaruh yang signifikan prestasi belajar (X4) terhadap kesiapan kerja mahasiswa ormawa (Y); dan (5) ada pengaruh yang signifikan gaya kepemimpinan (X1), kemampuan manajerial (X2), efikasi diri (X3), dan prestasi belajar (X4) terhadap kesiapan kerja mahasiswa ormawa (Y).

\section{DAFTAR RUJUKAN}

ACT. (2013). Work Readiness Standards and Benchmarks: The Key to Differentiation America's Workforce and Regaining Global Competitiveness. (Online), (http://workreadycommunities.org/resources/Standards-andBenchmarks.pdf), diakses 24 Agustus 2019.

Alhusin, S. (2003). Aplikasi Statistik Praktis dengan SPSS 10 for Windows. Yogyakarta: Graha Ilmu.

Alwisol. (2007). Psikologi Kepribadian. Malang: UMM Press.

Anderson, L. W., \& Krathwohl, D. R. (2001). A Taxonomy for Learning, Teaching, and Assesing: A Revision of Bloom's Taxonomy of Educatioanl Objectives. New York: Addison Wesley Longman, Inc.

Anthony, L. D. (2005). Self-Efficacy and Work-Readiness of Disadvantaged Females. Disertasi tidak diterbitkan. Athens, Georgia: The University of Georgia.

Argadinata, H., \& Gunawan, I. (2019). The Leadership of Pancasila in Education: Foundation for Strengthening Student Characters in the Industrial Revolution Era 4.0. The 4th International Conference on Education and Management (COEMA 2019). Atlantis Press.

Arnold, J., \& Mackenzie-Davey, K. (1992). Self-Ratings and Supervisor Ratings of Graduate Employees' Competencies During Early Career. Journal of Occupational and Organizational Psychology, 65, 235-250.

Ary, D., Jacobs, L. C., \& Razavieh, A. (1982). Pengantar Penelitian dalam Pendidikan. Terjemahan oleh Arief Furchan. Surabaya: Usaha Nasional.

Astuti, J. S. (2011). Gaya Kepemimpinan Mahasiswa Unit Kegiatan Mahasiswa. Tesis tidak diterbitkan. Malang: Universitas Negeri Malang.

Bafadal, I., Sobri, A. Y., Nurabadi, A., \& Gunawan, I. (2019). Standards of Competency of Head of School 
Beginners as Leaders in Learning Innovation. 5th International Conference on Education and Technology (ICET 2019). Atlantis Press.

Baiti, R. D., Abdullah, S. M., \& Rochwidowati, N. S. (2017). Career Self-Efficacy dan Kesiapan Kerja pada Mahasiswa Semester Akhir. Jurnal Psikologi Integratif, 5(2), 128-141.

Baker, S. B., Foxx, S. P., Akcan-Aydin, P., Williams, R. G., Ashraf, A., \& Martinez, R. R. (2019). Psychometric Properties of the Career and College Readiness Self-Efficacy Inventory. VISTAS, 1-13.

Bandaranaike, S., \& Willison, J. (2015). Building Capacity for Work-Readiness: Bridging the Cognitive and Affective Domains. Asia-Pacific Journal of Cooperative Education, 16(3), 223-233.

Bandura, A. (1978). Self-Efficacy: Toward a Unififying Theory of Behavioral Change. Advances in Behaviour Research and Therapy, 1(4), 139-161.

Bandura, A. (1986). Social Foundations of Thought and Action: A Social Cognitive Theory. Englewood Cliffs, NJ: Prentice-Hall.

Bandura, A. (1989). Regulation of Cognitive Processes Through Perceived Self-Efficacy. Developmental Psychology, 25(5), 729-735.

Bandura, A. (1991). Self Efficacy Mechanism in Psychological and Health-Promoting Behavior. New Jersey: Prentice Hall.

Bandura, A. (1993). Perceived Self-Efficacy in Cognitive Development and Functioning. Educational Psychologist, 28(2), 117-148.

Bandura, A. (1997). Self-Efficacy: The Exercise of Control. New York: WH Freeman, Times Books, Henry Holt $\&$ Co.

Bandura, A. (2005). Theories of Personality: Social Cognitive Theory. New York: TheMc Graw-Hill Companies.

Bills, D. B. (1998). Credentials and Capacities: Employers' Perceptions of the Acquisition of Skills. The Sociological Quarterly, 29(3), 439-449.

Braverman, H. (2018). Labor and Monopoly Capital: The Degradation of Work in the Twentieth Century. New York: Monthly Review Press.

Cohen, J. (2013). Applied Multiple Regression or Correlation Analysis for the Behavioral Science. Englewood Cliffs: Lawrence Erlbaum Associates Publishers.

Cruzvergara, C., Y., Testani, J., \& Smith, K. K. (2018). Leadership Competency Expectations of Employers and the Expanding Mission of Career Centers. New Directions for Student Leadership, 157, 27-37.

Doe, R. (2015). Work Readiness among Graduate Students. Disertasi tidak diterbitkan. Louisiana: Louisiana State University.

Draper, N. R., \& Smith, H. (2016). Applied Regression Analysis. New York: John Wiley and Sons, Ltd.

Faizah, D. A., \& Indrawati, A. (2017). Effect of Learning Achievement of the Eye of Productive Training, Prakerin Experience, and Interests in Student Readiness Entering the World of Work. Jurnal Pendidikan Bisnis dan Manajemen, 3(3), 179-191.

Fox, K. F. (2018). Leveraging a Leadership Development Framework for Career Readiness. New Directions for Student Leadership, 157, 13-26.

Gabric, D., \& McFadden, K. (2001). Student and Employer Perceptions of Desirable Entry-Level Operations Management Skills. Mid-American Journal of Business, 16(1), 51-59.

Gist, M. E. (1987). Self-Efficacy: Implication for Organizational Behavior and Human Resource Management. Academy of Management Review, 12, 472-485.

Grummon, T. H. (1997). Centerfocus Number 15: Assessing Students for Workplace Readiness. Berkeley, CA: Institute for Research on Teaching Adults. (Online), (http://ncrve.berkeley.edu/CenterFocus/cfl5.html), diakses 24 Agustus 2019.

Gunawan, I. (2013). Statistika untuk Kependidikan Sekolah Dasar. Yogyakarta: Penerbit Ombak.

Gunawan, I. (2016). Pengantar Statistika Inferensial. Jakarat: Rajawali Pers.

Gunawan, I. (2017). Prestasi Belajar Mahasiswa Fungsionaris UKM KSR PMI Unit Universitas Negeri Malang. Ilmu Pendidikan: Jurnal Kajian Teori dan Praktik Kependidikan, 2(2), 171-177.

Gunawan, I. (2018). Kepemimpinan Pendidikan: Suatu Pengantar. Malang: Universitas Negeri Malang, UM Press. Gunawan, I. (2019). Develop Educational Leadership by Applying Values and Ethics to Strengthen Student Character. 5th International Conference on Education and Technology (ICET 2019). Atlantis Press.

Gunawan, I., Benty, D. D. N., Kusumaningrum, D. E., Sumarsono, R. B., Sari, D. N., Pratiwi, F. D., ... \& Hui, L. K. (2019a). Validitas dan Reliabilitas Angket Keterampilan Manajerial Mahasiswa. JAMP: Jurnal Administrasi 
dan Manajemen Pendidikan, 2(4), 247-257.

Gunawan, I., Kusumaningrum, D. E., \& Sumarsono, R. B. (2019b). Investigation of Principal Leadership Based on Pesantren: Descriptive Study about Implementation of Human Resources Empowerment Models Based on Soft System Methodology. The 4th International Conference on Education and Management (COEMA 2019). Atlantis Press.

Gunawan, I., Suminah, Murdiyah, S., Andriningrum, H., \& Onenda, G. (2018a). Improving Student Learning Achievement through Behavior Modification Approach. 1st International Conference on Early Childhood and Primary Education (ECPE 2018). Atlantis Press.

Gunawan, I., Suminah, S., Murdiyah, S., Andriningrum, H., \& Onenda, G. (2018b). Improving Student Learning Achievement through Behavior Modification Approach. 1st International Conference on Early Childhood and Primary Education (ECPE 2018). Atlantis Press.

Gunawan, I., Ulfatin, N., Sultoni, S., Sunandar, A., Kusumaningrum, D. E., \& Triwiyanto, T. (2017a). Pendampingan Penerapan Strategi Pembelajaran Inovatif dalam Implementasi Kurikulum 2013. Abdimas Pedagogi: Jurnal Ilmiah Pengabdian kepada Masyarakat, 1(1), 37-47.

Gunawan, I., Ulfatin, N., Sultoni, S., Sunandar, A., Kusumaningrum, D. E., \& Triwiyanto, T. (2017b). Pendampingan Penerapan Strategi Pembelajaran Inovatif dalam Implementasi Kurikulum 2013 di MIS Lowokwaru Kota Malang. Laporan pengabdian kepada masyarakat tidak diterbitkan. Malang: Fakultas Ilmu Pendidikan Universitas Negeri Malang.

Hadi, S., Gunawan, I., \& Dalle, J. (2018). Statistika Inferensial: Teori dan Aplikasinya. Jakarta: Rajawali Pers.

Hansen, S. L., \& Hoag, B., A. (2018). Promoting Learning, Career Readiness, and Leadership in Student Employment. New Directions for Student Leadership, 157, 85-99.

Jaunarajs, I., \& McGarry, E. (2018). Organizational Alignment to Promote Leadership Development for Career Readiness in College Settings. New Directions for Student Leadership, 157, 101-113.

Karim, \& Hadi, S. (2007). Analisis Regresi Berganda dan Analisis Faktor. Banjarmasin: Program Studi Magister Manajemen Pendidikan Program Pascasarjana Universitas Lambung Mangkurat.

Kartono, K. (2010). Pemimpin dan Kepemimpinan. Jakarta: PT Rajawali Pers.

Katz, R. L. (2017). Skills of an Effective Administrator. Harvard: Harvard Business School Press.

Kholiq, A. (2011). Pengantar Manajemen. Semarang: Rafi Sarana Perkasa.

Komarraju, M., Musulkin, S., \& Bhattacharya, G. (2010). Role of Student-Faculty Interactions Indeveloping College Students' Academic Self-Concept, Motivation and Achievement. Journal of College Student Development, 51(3), 332-342.

Krejcie, R. V., \& Morgan, D. W. (1970). Determining Sample Size for Research Activities, Educational and Psychological Measurement, 30, 607-610.

Kusumaningrum, D. D. E., Ulfatin, N. N., Maisyaroh, M., Triwiyanto, T. T., \& Gunawan, I. (2017). Community Participation in Improving Educational Quality. 2nd International Conference on Educational Management and Administration (CoEMA 2017). Atlantis Press.

Kusumaningrum, D. E., Gunawan, I., Sumarsono, R. B., \& Triwiyanto, T. (2018). Panduan Pengelolaan Perpustakaan Sekolah Dasar. Malang: Universitas Negeri Malang, UM Press.

Leveson, L. 2000. Disparities in Perceptions of Generic Skills: Academics and Employers. Industry and Higher Education, 14(3), 157-164.

Lundberg, C. A., \& Schreiner, L. A. (2004). Quality and Frequency of Faculty-Student Interaction as Predictors of Learning: An Analysis by Student Race / Ethnicity. Journal of College Student Development, 45(5), 549-565.

Machida, M., \& Schaubroeck, J. (2011). The Role of Self-Efficacy Beliefs in Leader Development. Journal of Leadership \& Organizational Studies, 18(4), 459-468.

Makki, B. I., Javaid, M. U., \& Bano, S. (2016). Level of Work Readiness Skills, Career Self-Efficacy and Career Exploration of Engineering Students. NFC-IEFR Journal of Engineering and Scientific Research, 4, 91-96.

Makki, B. I., Salleh, R., Memon, M. A., \& Harun, H. (2015). The Relationship between Work Readiness Skills, Career Self-efficacy and Career Exploration among Engineering Graduates: A Proposed Framework. Research Journal of Applied Sciences, Engineering and Technology, 10(9), 1007-1011.

Mashigo, A. C. L. (2014). Factors Influencing Work Readiness of Graduates: An Exploratory Study. Tesis tidak diterbitkan. Stellenbosch: Stellenbosch University.

Mason, R. D., Lind, D. A., \& Marchal, W. G. (1988). Statistics An Introduction. San Diego: Harcourt Brace Jovanovich Publishers.

Mulyasa, E. (2004). Implementasi Kurikulum 2004: Panduan Pembelajaran KBK. Bandung: PT Remaja 
Rosdakarya.

Nurabadi, A., Gunawan, I., \& Sari, Y. L. (2019a). The Application of Informal Supervision to Improve the Quality of Learning in Laboratory Schools. The 4th International Conference on Education and Management (COEMA 2019). Atlantis Press.

Nurabadi, A., Sucipto, S., \& Gunawan, I. (2019b). Informal Supervision Model "Managing by Walking About" in Improving Quality of Learning. 5th International Conference on Education and Technology (ICET 2019). Atlantis Press.

Nurahman, D. O. (2017). Pengaruh Pelatihan Dasar Kepemimpinan terhadap Kesiapan Kerja di Balai Besar Pengembangan Latihan Kerja Semarang. Tesis tidak diterbitkan. Semarang: Universitas Negeri Semarang.

Pambudi, B. A., \& Gunawan, I. (2019). Instructional Leadership as an Effort to Increase Teacher Professionalism in the Industrial Revolution Era 4.0. The 4th International Conference on Education and Management (COEMA 2019). Atlantis Press.

Peck, A. (2018). Mapping Career-Ready Skills Through Student Leadership Programs. New Directions for Student Leadership, 157, 71-83.

Prastiawan, A., Gunawan, I., Putra, A. P., Surahman, E., Dewantoro, D. A., ... \& Nuraini, N. L. S. (2019). Office Management of Educational Institutions: Theories and Applications. 5th International Conference on Education and Technology (ICET 2019). Atlantis Press.

Putri, A. F., Andriningrum, H., Rofiah, S. K., \& Gunawan, I. (2019). Teacher Function in Class: A Literature Review. 5th International Conference on Education and Technology (ICET 2019). Atlantis Press.

Riduwan, \& Kuncoro, E. A. (2017). Cara Menggunakan dan Memaknai Analisis Jalur (Path Analysis). Bandung: Alfabeta.

Robbins, S. P., \& Judge, T. A. (2017). Organizational Behavior. New Jersey: Pearson Education.

Salladien. (1997). Metodologi Penelitian Pendidikan. Malang: IKIP Malang.

Santoso, S. (2010). Buku Latihan SPSS Statistik Parametrik. Jakarta: Gramedia.

Saputra, B. R., Adha, M. A., Ariyanti, N. S., \& Gunawan, I. (2019). Tips for Principal in Managing One Roof School (SATAP) in Underdeveloped Area. The 4th International Conference on Education and Management (COEMA 2019). Atlantis Press.

Seemiller, C. (2018). Enhancing Leadership Competencies for Career Readiness. New Directions for Student Leadership, 157, 39-53.

Setiawan, I. G. A. N. (2008). Penerapan Pengajaran Kontekstual Berbasis Masalah untuk Meningkatkan Hasil Belajar Biologi Siswa Kelas X-2 SMA Laboratorium Singaraja. Jurnal Penelitian dan Pengembangan Pendidikan, 2(1), 42-59.

Setyadin, B. (2005b). Desain dan Metode Penelitian Kuantitatif. Modul IV disajikan dalam Penataran Tenaga Fungsional Akademik Politeknik Kotabaru, Lembaga Penelitian Universitas Negeri Malang, Kotabaru Kalimantan Selatan, 15 - 22 Februari 2005.

Setyadin, B. (bsyadin@yahoo.com).(30 Mei 2007).Analisis Jalur.e-mail kepada Imam Gunawan (masimamgun@, yahoo.com).

Singarimbun, M., \& Effendi, S. (1989). Metode Penelitian Survey. Jakarta: LP3S.

Sjukur, S. B. (2012). Pengaruh Blended Learning terhadap Motivasi Belajar dan Hasil Belajar Siswa Tingkat SMK. Jurnal Pendidikan Vokasi, 2(3), 368-378.

Sobri, A. Y., Bafadal, I., Nurabadi, A., \& Gunawan, I. (2019). Validity and Reliability of Questionnaire Problematics Leadership Beginner School Principals. The 4th International Conference on Education and Management (COEMA 2019). Atlantis Press.

Soetopo, H. (2001). Hubungan Karakteristik Bawahan, Kontrol Situasi, Perilaku Kepemimpinan, Budaya Organisasi, dan Iklim Organisasi dengan Keefektifan Organisasi pada Universitas Swasta di Kotamadya Malang. Disertasi tidak diterbitkan. Malang: Program Pascasarjana Universitas Negeri Malang.

Stiawan, Y. A. (2013). Hubungan Kecerdasan Emosi - Sosial terhadap Gaya dan Praktik Kepemimpinan Ketua Lembaga Kemahasiswaan Institut Pertanian Bogor. Tesis tidak diterbitkan. Bogor: Institut Pertanian Bogor.

Sudarmanto, R. G. (2005). Analisis Regresi Linear Ganda dengan SPSS. Yogyakarta: Graha Ilmu.

Sudjana, N. (1998). Metode Statistika. Bandung: Tarsito.

Sultoni, Gunawan, I., \& Rosalinda, T. N. (2018a). Pengaruh Pembentukan Tim dan Kepemimpinan Spiritual terhadap Motivasi Diri Mahasiswa. JMSP: Jurnal Manajemen dan Supervisi Pendidikan, 2(3), 210-216.

Sultoni, Gunawan, I., \& Rosalinda, T. N. (2018b). Upaya Mahasiswa dalam Menyiapkan Diri Masuk ke Dunia Kerja: Suatu Kajian Deskriptif. Seminar Nasional Pendidikan, Tema: Mendidik Cerdas Generasi Digital, 
Fakultas Ilmu Pendidikan Universitas Negeri Malang, 1(1), 143-148.

Sultoni, Gunawan, I., \& Sari, D. N. (2019). Validity and Reliability of Character Education Internalization Instruments. The 4th International Conference on Education and Management (COEMA 2019). Atlantis Press.

Sumarsono, R. B., Kusumaningrum, D. E., Gunawan, I., Alfarina, M., Romady, M., Ariyanti, N. S., \& Budiarti, E. M. (2019). Training on the Implementation of Cooperative Learning Models as an Effort to Improve Teacher's Performance. The 4th International Conference on Education and Management (COEMA 2019). Atlantis Press.

Tamrat, W. (2019). Work-Ready Graduates Require Strong Partnerships, (Online), (https://www.insidehighered. com/blogs/world-view/work-ready-graduates-require-strong-partnerships), diakses 2 November 2019.

Tentama, F., Merdiaty, N., \& Subardjo. (2019). Self-Efficacy and Work Readiness among Vocational High School Students. Journal of Education and Learning (EduLearn), 13(2), 277-281.

Thoha, M. (2014). Perilaku Organisasi: Konsep Dasar dan Aplikasinya. Jakarta: Rajawali Pers.

Tschirgi, H. D. (1972). What do Recruiters Really Look for in Candidates? Journal of College Placement, 33, $75-79$.

Tu’u, T. (2004). Peran Disiplin pada Perilaku dan Prestasi Siswa. Jakarta: Grasindo.

Winarsunu, T. (2012). Statistik dalam Penelitian Psikologi dan Pendidikan. Malang: Universitas Muhammadiyah Malang.

Wiyono, B. B., \& Sunarni. (2009). Evaluasi Program Pendidikan dan Pembelajaran. Malang: Fakultas Ilmu Pendidikan Universitas Negeri Malang.

Yi-Li, J., Y., \& Goh, L. L. (2011). The Role of Self-Efficacy on Job Readiness and Career Choice among People with Intellectual Disability in Singapore. Journal of the American Academy of Special Education Professionals, 93-11.

Yuliani, L., \& Yuniarsih, T. (2019). Influence of Industrial Work Practices and Learning Achievements on Students Work Readiness. Proceedings of the 1st International Conference on Economics, Business, Entrepreneurship, and Finance (ICEBEF 2018), Atlantis Press, 65, 188-191. 